\title{
39. EARLY CRETACEOUS BIOGEOGRAPHIC AND OCEANOGRAPHIC SYNTHESIS OF LEG 123 (OFF NORTHWESTERN AUSTRALIA) ${ }^{1}$
}

\author{
Peter O. Baumgartner, ${ }^{2}$ Paul Bown, ${ }^{3}$ Jean Marcoux,${ }^{4}$ Jorg Mutterlose,${ }^{5}$ Mike Kaminski, ${ }^{6}$ David Haig, ${ }^{7}$ and \\ Andrew McMinn ${ }^{8}$
}

\begin{abstract}
Biogeographic observations made by Leg 123 shipboard paleontologists for Lower Cretaceous nannofossils, foraminifers, radiolarians, belemnites, and inoceramids are combined in this chapter to evaluate the paleoceanographic history of the northwestern Australian margin and adjacent basins. Each fossil group is characterized at specific intervals of Cretaceous time and compared with data from Tethyan and Southern Hemisphere high-latitude localities. Special attention is given to the biogeographic observations made for the Falkland Plateau (DSDP Legs 36 and 71) and the Weddell Sea (ODP Leg 113). Both areas have yielded valuable Lower Cretaceous fossil records of the circumantarctic high latitudes.

In general, the Neocomian fossil record from DSDP and ODP sites off northwestern Australia has important southern high-latitude affinities and weak Tethyan influence. The same is true for the pelagic lithofacies: radiolarian chert and/or nannofossil limestone, dominant in the Tethyan Lower Cretaceous, are minor lithologies in the Exmouth-Argo sites. These observations, together with the young age of the Argo crust and plate tectonic considerations, suggest that the Argo Basin was not part of the Tethys Realm.

The biogeography of the Neocomian radiolarian and nannofossil assemblages suggests opening of a seaway during the Berriasian that connected the circumantarctic area with the Argo Basin, which resulted in the influx of southern high-latitude waters.

This conclusion constrains the initial fit and break-up history of Gondwana. Our results favor the loose fit of the western Australian margin with southeast India by Ricou et al. (1990), which accounts for a deeper water connection with the Weddell-Mozambique basins via drowned marginal plateaus as early as the Berriasian. In fits of the du Toit-type (1937), India would remain attached to Antarctica, at least until the late Valanginian, making such a connection impossible.

After the Barremian, increasing Tethyan influence is evident in all fossil groups, although southern high-latitude taxa are still present. Biogeographic domains, such as the southern extension of Nannoconus and Ticinella suggest paleolatitudes of about $50^{\circ} \mathrm{S}$ for the Exmouth-Argo area. Alternatively, if paleolatitudes of about $35^{\circ}$ are accepted, these biogeographic limits were displaced northward at least $15^{\circ}$ along Australia in comparison to the southern Atlantic. In this case, the proto-circumantarctic current was deflected northward into an eastern boundary current off Australia and carried circumantarctic cold water into the middle latitudes.

Late Aptian/early Albian time is characterized by mixing of Tethyan and southern faunal elements and a significant gradient in Albian surface-water temperatures over $10^{\circ}$ latitude along the Australian margin, as indicated by planktonic foraminifers. Both phenomena may be indicative of convergence of temperate and antarctic waters near the Australian margin. High fertility conditions, reflected by radiolarian cherts, are suggestive of coastal upwelling during that time.
\end{abstract}

\section{INTRODUCTION}

During Legs 122 and 123 of the Ocean Drilling Program, scientists drilled two transects across the northwestern Australian margin (Fig. 1) to explore a possible remnant of the northern Gondwanan margin that faced the Jurassic Tethys Ocean.

Oxfordian (M26) oceanic crust, a relic of ancient ocean floor older than any previously drilled in the Indian Ocean, was expected to underlie Upper Jurassic sediments at Site 765 in the Argo Abyssal Plain. The Mesozoic sediment column was assumed to resemble Tethyan sections exposed in the Alpine-Himalayan mountain belt.

\footnotetext{
${ }^{1}$ Gradstein, F. M., Ludden, J. N., et al., 1992. Proc. ODP, Sci. Results, 123: College Station, TX (Ocean Drilling Program).

2 Institut de Géologie, BFSH2, CH-1015 Lausanne, Switzerland.

${ }^{3}$ Department of Geology, University College, London, Gower Street, London WCIE 6BT, U.K.

${ }_{5}^{4}$ Université de Paris VII, 2 Place Jussieu, 75221 Paris Cedex 05, France.

${ }_{6}^{5}$ Department of Geology, University of Nebraska, Lincoln, NE 68588, U.S.A.

${ }^{6}$ Geomar, Wischostrasse 1-3, 2300 Kiel 14, Germany.

${ }^{7}$ Department of Geology, University of Western Australia, Nedlands, 6009 Australia.

${ }^{8}$ Geological Survey of New South Wales, Kensington 2300, N.S.W. Australia.
}

Surprisingly, no dated Jurassic sediments were found; the oldest sediment at Site 765 has been interpreted as Tithonian or older, based on facies analogies with DSDP Site 261 (Dumoulin and Bown, this volume), but may be as young as Berriasian. Although radiometric basement ages of $155 \mathrm{~m} . \mathrm{y}$. (Ludden, this volume) seem to confirm the inferred sediment age, this margin is still younger than most Neotethys margins, known from the Mediterranean region to Oman and the Himalayas.

Similarly, Cretaceous deep-water sedimentary facies and fossil assemblages cored off northwestern Australia have only weak comparisons with coeval typical Tethyan facies. The Lower Cretaceous sequences cored in the Argo Basin are dominated by clay-rich sediments, whereas either nannofossils and/or radiolarians constitute an important proportion of pelagic sediments in typical Tethyan sequences. All recovered fossil groups have significant differences in faunal composition, abundance, and/or stratigraphic range with respect to Tethyan sequences. These differences were noticed by the shipboard biostratigraphers and are mentioned in several chapters in this volume. However, nonTethyan species are generally under-represented in the biostratigraphic chapters because most classical biozonations were established in the Tethyan Realm and are based on typical Tethyan species. We find revealing similarities between these non-Teth- 


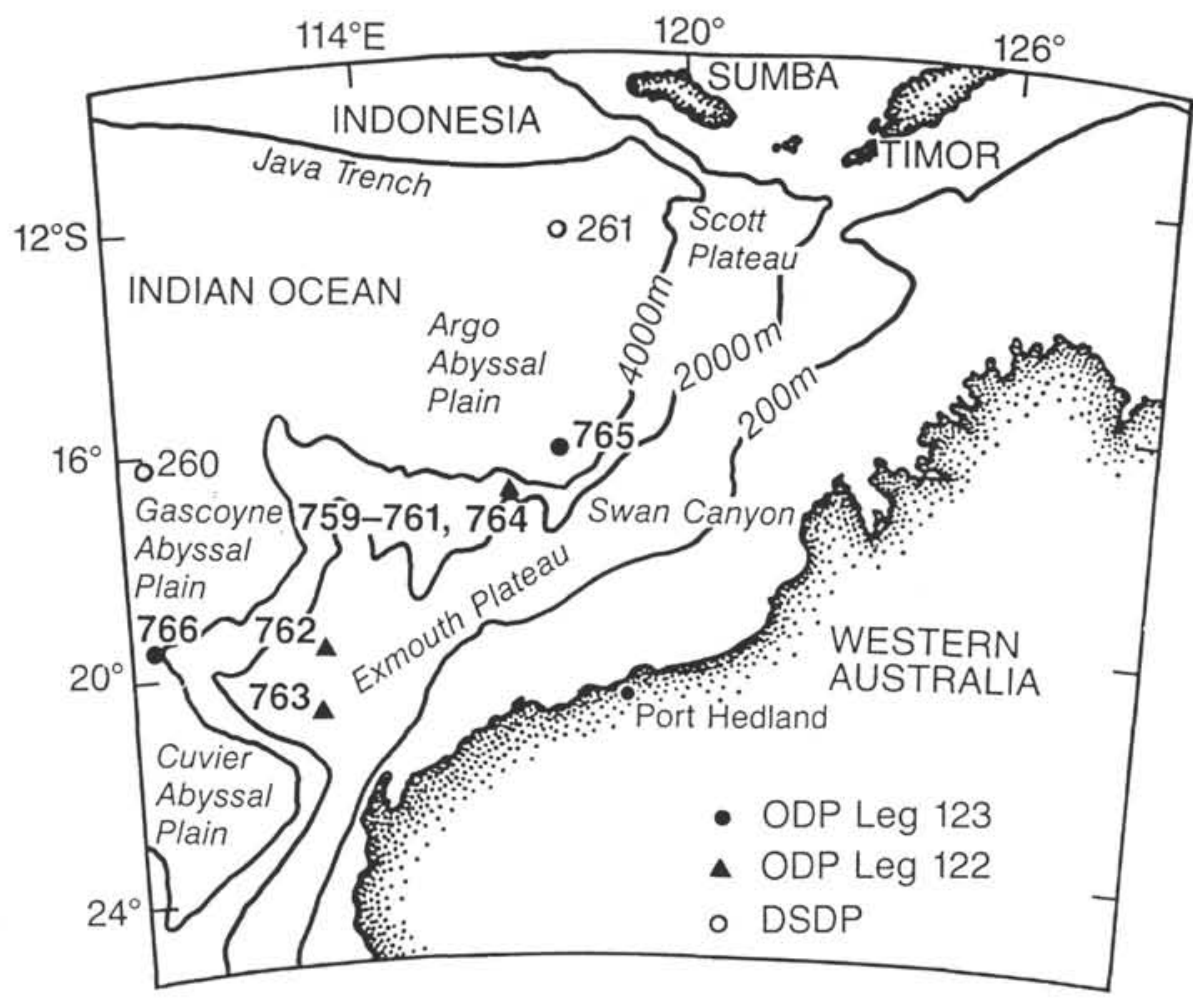

Figure 1. Geography of northwestern Australia and surrounding ocean basins and location of Leg 122 and 123 sites and DSDP Leg 27 sites.

yan occurrences and reports from DSDP and ODP sites in southern middle and high paleolatitudes.

The objectives of this chapter are (1) to summarize paleobiogeographic information obtained from biostratigraphic data, (2) to compare it with other fossil records from the southern middle and high paleolatitudes, and (3) to interpret our findings in terms of paleoceanographic connections between the Southern Ocean and the Exmouth-Argo Basin area during Early Cretaceous time.

The paleoceanography of middle- to high-latitude waters has been particularly sensitive to regional and global climatic changes. We attempt to establish causal relationships among interpretive paleoceanography, plate-tectonic configurations, and fluctuations in global sea level during the Early Cretaceous.

\section{BIOGEOGRAPHIC OBSERVATIONS OF EACH FOSSIL GROUP}

\section{Calcareous Nannofossils}

\section{Introduction}

Calcareous nannoplankton in today's oceans display distinctive provinciality, which is broadly latitudinal and related to temperature and nutrient characteristics of water masses (McIntyre and Bé, 1967; Tappan, 1980). Provincialism in the fossil record has been recognized in varying degrees (e.g., Haq and Lohman, 1976 [early Cenozoic]; Pospichal and Wise, 1990 [Late Cretaceous]; Crux, 1989; Mutterlose, 1989; Roth and Krumbach, 1986 [Early Cretaceous]; Cooper, 1989 [Late Jurassic]; and Bown, 1987 [Early Jurassic]). However, much of the data are geographically restricted, and causal factors are poorly understood. In the Late Jurassic to Early Cretaceous interval, provincialism has been well documented for the North AtlanticEuropean region, where biogeographic differentiation occurred between a northern mid-high-latitude Boreal Realm and a lowlatitude Tethyan Realm (e.g., Mutterlose, 1989; Crux, 1989). More recently, DSDP/ODP sites from the southern oceans, the Falkland Plateau, and the Weddell Sea (Fig. 2) provided data that indicate the existence of a southern mid-high-latitude Austral Realm. In the Lower Cretaceous, these data are limited to the Valanginian and Aptian-Albian, but are far more complete for the Upper Cretaceous (Wise, 1983; Pospichal and Wise, 1990; Mutterlose and Wise, 1990).

Nannofloral provincialism has been recognized primarily by the occurrence of endemic species and dissimilar assemblage compositions (e.g., shifts in species dominance). Nannofloral distribution in the Upper Cretaceous broadly defines a low-latitude subtropical-to-tropical belt flanked to the north and south by the Boreal and Austral realms. Although much less data exist for the Lower Cretaceous, a similar distribution was expected and has been confirmed to some extent by species that may be endemic to the Boreal or Tethyan realms. A number of species, suspected to be endemic to the Boreal Realm by earlier scientists, display distinctive bipolar distribution patterns (e.g., Crucibiscutum salebrosum and Seribiscutum primitivum, Mutterlose and Wise, 1990; Mutterlose, this volume; Bown, this volume). The distribution of these forms in the Southern Hemisphere may become a useful criterion for defining the Austral Realm.

\section{Biogeographic Implications of Calcareous Nannofossils from Sites 261 and 765 and 766}

Upper Jurassic-Lower Cretaceous nannofossils show a relatively distinct provincialism similar to that exhibited by macrofaunas, such as ammonites, belemnites, brachiopods, and bivalves. Above the Barremian/Aptian boundary, however, a major faunal/floral change can be observed that is accompanied by a more cosmopolitan distribution. The nannofloras from Sites 261, 765 , and 766 thus are described from appropriate time slices: 


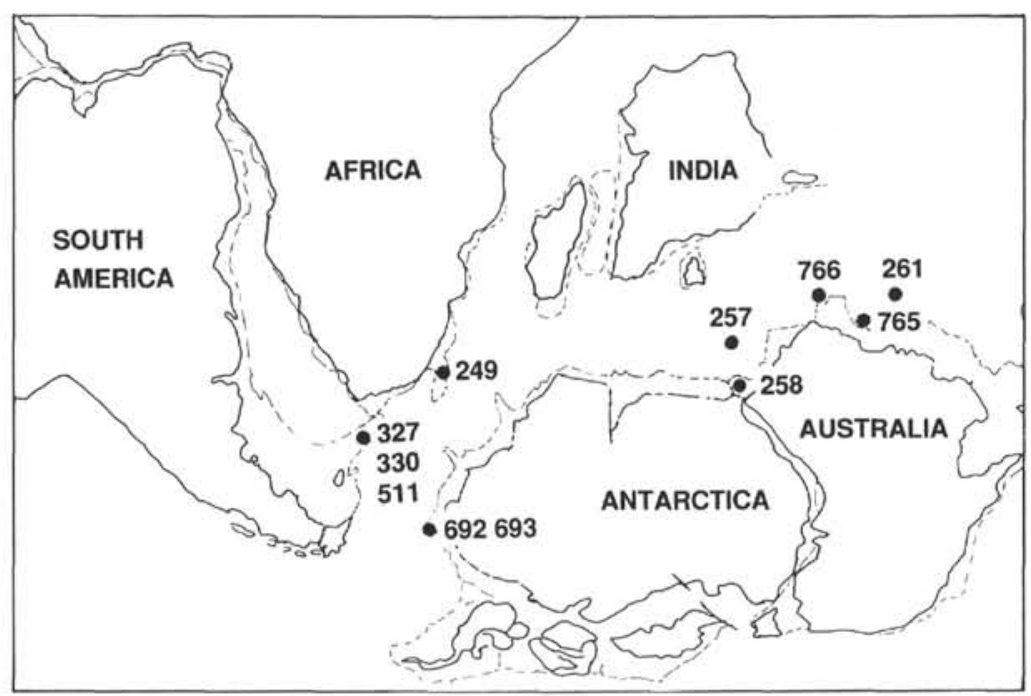

Figure 2. Generalized paleogeography of the Southern Hemisphere, derived from Ricou et al. (1990) and Ricou et al. (pers. comm., 1991), early Aptian, 118 m.y. ago (M0), with the approximate position of DSDP and ODP sites discussed in the text. For further details see Figure 5.

Kimmeridgian(?)-Tithonian, Berriasian-Barremian, and AptianAlbian.

\section{Kimmeridgian(?)-Tithonian (Sites 261 and 765)}

Only a poorly preserved nannoflora, of possible Tithonian age, was observed from Site 765. The information that follows thus was taken largely from Site 261, where moderately well-preserved Late Jurassic nannofloras occur at the base of the cored section (Proto Decima, 1974; Dumoulin and Bown, this volume).

The Kimmeridgian(?)-Tithonian nannofloras are predominantly made up of cosmopolitan taxa (e.g., the dominant Watznaueria britannica, along with Stephanolithion bigotii, Cyclagelosphaera margerelii, and Zeugrhabdotus embergeri). Affinities with the Tethyan Realm are suggested by the occurrence of Conusphaera mexicana minor (rare) and Watznaueria manivitae; neither species is known from either the Boreal or the Austral realms at this time. The absence of taxa having bipolar distribution for this interval prevents any positive argument in favor of austral, high-latitude affinities. However, apart from the two species listed above, the assemblages lack many of the most characteristic Tethyan taxa, particularly Nannoconus and Conusphaera mexicana. Consequently, by negative implication, these assemblages are not truly Tethyan. The dominance of $W$. manivitae and the presence of Cyclagelosphaera argoensis and Zeugrhabdotus cooperi appear to be unique to these sites.

\section{Berriasian-Barremian (Sites 261, 765, and 766)}

Nannofloras for this interval from Sites 261, 765, and 766 are composed predominantly of cosmopolitan taxa (e.g., Watznaueria barnesae, W. fossacincta, Lithraphidites carniolensis, Microstaurus chiastius, and Manivitella pemmatoidea). However, a number of significant occurrences and omissions indicate that these assemblages combine Boreal/Austral higher-latitude affinities with some Tethyan influences.

The most positive proof of high-latitude affinities is given by the common and consistent occurrence since the Berriasian (above Event 1, Fig. 3) of Crucibiscutum salebrosum, which is not found in the Tethyan Realm. The occurrence in the Southern Hemisphere of this species, from Falkland Plateau and Weddell Sea sites (Wise, 1983; Mutterlose and Wise, 1990), is confirmed here and further demonstrates its striking bipolar distribution.
Additional evidence for higher-latitude affinities includes the absence of a number of characteristic Tethyan taxa, in particular, the Nannoconus group. In addition, the species Rhagodiscus asper, which is a common component of Tethyan assemblages, was observed only rarely. Although these features suggest higherlatitude affinities, the assemblages lack species that are typical for the Boreal Realm, for instance, Micrantholihtus speetonensis, Kokia spp., Nannoconus borealis, and Corollithion silvaradion. At present, a bipolar distribution of these taxa cannot be established.

Evidence for Tethyan influence in these nannofloras is provided by occurrences of Cruciellipsis cuvillieri, Tubodiscus verenae, and Speetonia colligata. However, these species also are rare and inconsistent in the Boreal Realm, where their presence is thought to indicate temperature increases related to climatic change or Tethyan/Boreal influxes of water masses (Crux, 1989; Mutterlose, 1989). These taxa are virtually absent at other southern ocean sites (one specimen of $C$. cuvillieri was reported from Site 692, Weddell Sea).

The occurrence of Vagalapilla matalosa in the Valanginian to Hauterivian is unique to Sites 261,765 , and 766 . This species has been recorded previously only from the late Barremian (e.g., Crux, 1989).

\section{Aptian-Albian (Sites 765 and 766)}

Generally, nannofloras from this interval tend to display a far greater degree of geographic homogeneity (Mutterlose, in press). The assemblages from Sites 765 and 766 are composed of cosmopolitan species, many of which have stratigraphic ranges that include the Neocomian, together with the first appearances of many species, for instance, Chiastozygus litterarius, Flabellites biforaminis, and Eprolithus apertior. However, the assemblages of these sites also display a number of taxa that indicate the continuation of biogeographic differentiation. Most importantly, Nannoconus is either absent or extremely rare, although this group is common in the Tethys and also can be found in the North Sea (Boreal Realm). In the southern ocean sites, Nannoconus generally is absent, but has been recorded in the upper Aptian of Site 511 (Falkland Plateau, Fig. 2), where it is thought to reflect a brief increase in water temperature. The presence of Seribiscutum primitivum also indicates continued differentiation. A 




Figure 3. Lower Cretaceous cores, age, lithology, and generalized abundances of the principal fossil groups recovered at Site 765 and paleoceanographic interpretation. The column "Cluster Analysis" (taken from Ludden, Gradstein, et al., 1990, Chapter 4, back-pocket chart) shows lithologic variation vs. depth following smear slide data (see text). The principal paleoceanographic events have been marked with the numbers 1 through 6 in Figures 3 through 6 and are discussed in the text. "M11" and "M0" mark the inferred or observed level of these magnetic anomalies and refer to the plate-tectonic reconstructions given in Figure 5. Note that lithologic variation closely matches with faunal evolution. 
high-latitude bipolar distribution has been discovered for this species by Roth and Krumbach (1986) and Mutterlose and Wise (1990).

\section{Discussion}

The principal factors governing the distribution of calcareous nannoplankton are temperature, nutrient availability, and water depth. The degree to which each of these factors controlled distributions during the Mesozoic is still uncertain. However, a number of the distribution patterns described above, particularly bipolar distribution and the absence of certain Tethyan taxa, are best explained by temperature control. The biogeographic differences recorded from the Argo sites and other southern ocean sites may reflect latitudinal changes in temperature and/or the effects of ocean currents.

The striking bipolar distribution of Crucibiscutum salebrosum and Seribiscutum primitivum suggests that these species were restricted to mid- to high-latitude, cool surface waters. The distribution of $C$. salebrosum was restricted to $40^{\circ}$ to $50^{\circ} \mathrm{N}$ and $35^{\circ}$ to $55^{\circ} \mathrm{S}$, while $S$. primitivum was restricted to $40^{\circ}$ to $50^{\circ} \mathrm{N}$ and $35^{\circ}$ to $60^{\circ} \mathrm{S}$ (Mutterlose, this volume). Their presence at Sites 261, 765 , and 766 may be an indication of the cold-water tolerances of these assemblages. They are more akin to the assemblages of the northern Boreal Realm and suggest the existence of a Southern Hemisphere equivalent, that is, the Austral Realm.

The distribution of Tethyan Nannoconus species can be similarly explained by temperature control (Mutterlose, 1989; Dumoulin and Bown, this volume). These nannoplankton are restricted to warm surface waters, and their virtual absence at the Argo and other southern ocean sites substantiates the existence of a southern mid- to high-latitude Austral Realm (Dumoulin and Bown, this volume). The rarity of Rhagodiscus asper also is thought to reflect cold surface-water temperatures (Erba, 1987).

Although the evidence stated above suggests that the Argo area was "Austral" in nature, evidence also exists of at least some Tethyan influence, as shown by the presence of $T$. verenae, $C$. cuvillieri, and $S$. colligata. However, these species may have been more tolerant of cold, because they also extend northward into the Boreal area. This mixing of nannofloral types suggests that the Argo area was transitional between the Tethyan and Austral realms and allowed for the coexistence of certain taxa from both areas, perhaps at the limit of their ecological tolerance. Certain Tethyan nannoplankton, such as Nannoconus, may have been thermophylic and unable to survive at middle latitudes, whereas more cool-tolerant species, such as those listed above, were able to coexist with typically temperate forms, such as $C$. salebrosum. In addition to the species that display bipolar distribution, the Austral Realm also may have included species that were confined to the Southern Hemisphere. Similarly, some Boreal taxa were confined to the Northern Hemisphere. The best example of a probable endemic Austral Realm species for the Neocomian interval is Vagalapilla matalosa.

\section{Radiolarians}

\section{Introduction}

Studies of Holocene and Neogene radiolarians recovered from oceanic surface sediments have demonstrated the existence of radiolarian provinces in all oceans (Petrushevskaya, 1971a, 1971b; Caulet, 1974; Renz, 1976; Kling, 1976; Labracherie and Moyes, 1978; Casey et al., 1979a, 1979b, 1979c; Goll and Bjorklund, 1972, 1974; Sancetta, 1978; Johnson and Nigrini, 1980). Radiolarian faunal provinces closely reflect surface oceanic current systems and water masses, which are broadly controlled by latitude, climate, and ocean geometry. These various bioprov- inces are characterized by distinct changes in abundance or by the presence or absence of certain radiolarian species or species groups. In addition, many provinces are characterized by the presence of endemic species, especially in the high latitudes and in restricted areas. Bipolar distribution of certain radiolarian taxa is well established for the Neogene and Holocene (Nigrini, 1967).

Pessagno and Blome (1986) defined criteria for determining the paleolatitude of Jurassic radiolarian assemblages. They suggested that abundance and diversity of pantanellids and of "Ristola"-type nassellarians are highest in the Tethyan (read: low latitude) Realm and decrease toward northern paleolatitudes. High abundance of "Parvicingula"-type nassellarians characterized the "northern Tethyan" faunal realm, whereas the total absence of pantanellids and "Ristola"-type taxa characterized the Boreal (read: northern middle to high latitude) Realm. Plots of abundance and latitude (Pessagno and Blome, 1986, fig. 7.2) suggest that even numerical paleolatitude values can be derived from radiolarian abundances.

Although increasing evidence (Baumgartner, this volume) exists to support the fundamentals of the latitudinal trends of Pessagno and Blome (1986), their detailed paleolatitudinal interpretation must be treated with great caution for the following reasons. First, their biogeographic analysis was based exclusively on Jurassic radiolarian assemblages recovered from localities in western North America and Mexico that are located in more or less displaced terranes. No reference sections from the European Tethys or from localities having paleolatitudes known from paleomagnetic studies were included in their analysis. Second, Holocene and Neogene radiolarian thanatocenoses also closely match the oceanographic "anomalies" created by warm currents flowing toward higher latitudes on western ocean margins (e.g., Gulf, Kuroshio, Agulhas currents) and by cold waters flowing toward the equator on eastern ocean margins (Benguela, California, Peru, Western Australian currents). In the areas influenced by these currents, radiolarian thanatocenoses show significant deviations from the "normal" open-ocean latitudinal distribution that are caused by the latitudinal expatriation of radiolarian populations by the surface currents (Casey, 1971; Casey et al., 1979b). Third, the depth distribution of radiolarians in tropical waters has similarities to the latitudinal distributions, in that certain coldwater species found in high-latitude surface waters can exist in the cold intermediate and deep waters of the equatorial zone. In upwelling areas, deep (cold) water taxa are brought to the surface, where they experience mass mortality (Casey, 1971). Thus, thanatocenoses of low-latitude upwelling areas may contain assemblage components of middle- or high-latitude bioprovinces.

The strengths and exact paths of the eastern and western boundary currents and associated upwelling systems are particularly sensitive to changes in climate, both short-term (seasonal, El Niño) and longer-term (Milankovich, ice ages vs. ice-free times). Radiolarian assemblages from upwelling zones have proved be useful tracers of such climate changes (Labracherie, 1980; Casey et al., 1989). These considerations limit the degree to which paleolatitudes can be inferred from ancient radiolarian assemblages, but they may be useful for our assessment of the origin of the Lower Cretaceous radiolarians recovered during Leg 123.

\section{Biogeography of Early Cretaceous Radiolarians from Sites 261, 765 , and 766}

Abundant and well-preserved Early Cretaceous radiolarians recovered at Sites 765 and 766 are characterized by the paucity or almost complete absence of Tethyan taxa in parts of the cored sections. The Berriasian-early Aptian radiolarian record recovered at Site 765 is unique in its density of well-preserved assem- 
blages and in its faunal contents (see Baumgartner, this volume). Radiolarian assemblages preserved in claystones of Site 765 and assemblages that have been reexamined from DSDP Site 261 contrast markedly with the faunas recovered from radiolarian sand layers restricted to Site 765. Comparisons among these sites, as well as sedimentological observations, lead one to conclude that this faunal contrast results from a difference in provenance, rather than from hydraulic sorting.

\section{Clay Faunas}

Very low-diversity radiolarian assemblages are present in the prevailing claystones at Sites 261 and 765 . Dominant radiolarian groups include cryptocephalic and cryptothoracic nassellarians of the genera Holocryptocanium and Cryptamphorella and Archeodictyomitra brouweri s.l. The remainder of the assemblages is composed of Tricolocapsa spp., Sethocapsa spp., and other small nassellarians. This faunal composition is similar to that of Site 261 , Cores 30 to 23 (Renz, 1974, Table 5). The observed species are known from Tethys, Atlantic, Pacific, and Roti (Timor), where they occur in much lower abundances as components of much more diverse assemblages. Apparently, these species are not present in southern high latitudes (Ling and Lazarus, 1990). Such typical Tethyan species as Pantanellium spp. or Acanthocircus spp. are totally absent. Most of the non-Tethyan species that dominate the sand faunas also are absent.

Similar radiolarian faunas have been reported at two other localities. The MH-7 assemblage of Murchey (1984) from the Marin Headlands Terrane (northern California) is dominated by Holocryptocanium spp. Although this late Albian-early Cenomanian assemblage is definitely younger than the clay faunas considered here, the faunal character may have a common origin. The Marin Headlands exposures are considered to have been deposited under open-ocean conditions. During much of the Jurassic and Early Cretaceous, the Marin Headlands Terrane occupied a lowlatitude position, as documented by Tethyan radiolarian assemblages (Murchey, 1984; Murchey and Jones, 1984). By the late Albian, this terrane may have reached slightly higher latitudes, where low-fertility central water masses may have been characterized by the Holocryptocanium Assemblage.

Three samples from the Le May Group, Alexander Island, Antarctic Peninsula, have been reported to contain abundant cryptocephalic nassellarians, along with some pantanellids, Archeodictyomitra apiara and Acanthocircus dicranacanthos, which indicate both a "Tethyan" influence and a Neocomian age (Holdsworth and Nell, in press). According to the authors, model predictions suggest an origin at about $39^{\circ} \mathrm{S}$ for these assemblages, a value similar to the $35^{\circ}$ to $39^{\circ} \mathrm{S}$ paleolatitude determined for the Argo Basin (Ogg et al., this volume). The authors surmised a low-fertility central water-mass province from this fauna.

In view of these comparisons, the clay faunas have been interpreted as an autochthonous, oceanic association, in contrast to the sand faunas, which are clearly current transported and may have come from outside the studied area (see below). The clay fauna species are inferred to have been ecologically tolerant or opportunistic, and they may represent an impoverished subtropical fauna. In contrast with the two other reports of Holocryptocanium assemblages, Tethyan elements are totally absent. The number of taxa in the clay faunas is about 10 to 20 times less than typical Tethyan assemblages (e.g., localities in Oman, Umbria; according to Jud and Baumgartner, unpubl. data) and two to three times less than the coeval sand faunas. Similar low diversities have been reported from the Kimmeridge Clay of the North Sea (Dyer and Copestake, 1989). Modern radiolarian faunas of such low diversity have been reported only from fjords (Aarseth et al., 1975 ) and may indicate special oceanic conditions, such as isolated basins.

\section{Sand Faunas}

Distinctive radiolarite intervals were deposited during the Berriasian to Barremian at Site 765 . However, these sediments constitute less than $5 \%$ of the thickness of the total sequence. Sedimentary structures clearly indicate redeposition and concentration of radiolarians by hydrodynamic processes (e.g., winnowing bottom currents, contour currents, or for some of the layers, low-density turbidity currents). The Site 765 radiolarites represent far less sediment volume than Tethyan Mesozoic ribbon radiolarites, which are $10 \mathrm{~s}$ to $100 \mathrm{~s}$ of meters thick. In the $80-\mathrm{m}$ thick interval between Cores 123-765C-58R and -51R, a maximum of $3.5 \mathrm{~m}$ of radiolarite having silica concentrations as high as $85 \%$ to $100 \%$ was measured.

Radiolarian abundance is high, and although diversity is two to three times higher than for the clay faunas, it is still 5 to 10 times less than for Tethyan assemblages. Species typical of the clay faunas, for instance, cryptocephalic nassellarians and $\mathrm{Ar}$ chaeodictyomitra spp., are ubiquitous members of the sand assemblages and usually have relative abundances of $10 \%$ up to $40 \%$. Non-Tethyan species assigned to the genera (Cyrtocapsa, Eusyringium, and Parvicingula; see Baumgartner, this volume) dominate the sand faunas. A series of well-defined acmes of these species give each core a characteristic radiolarian assemblage. Some of these acmes also were observed at Site 766 (Fig. 4). Tethyan species are generally rare and almost absent in the early Valanginian to late Hauterivian interval (between events 2 and 3 , Figs. 3 and 4). Tethyan species gradually increase in abundance and diversity during the late Barremian-early Aptian.

\section{Discussion}

None of the non-Tethyan species recovered from the sand faunas are known from other localities. Similar species of Parvicingula and Ristola have been reported from New Zealand (Spörli and Aita, 1988; Spörli et al., 1989). Similar (but not identical) Parvicingula species also have been reported in the Middle Jurassic of the Blue Mountains, Oregon (Pessagno and Whalen, 1982) and in other Boreal localities of the Soviet Union (Vishnevskaya, 1988). "Parvicingula"-type forms dominate largely over those of "Ristola"-type in the sand faunas (for a discussion of the systematic usage of these groups see Pessagno, 1977; Baumgartner, 1984; and Baumgartner, this volume). Pantanelliids are absent from claystone assemblages and are rare in sand assemblages.

Hence, the sand faunas have at least some similarities to northern high-latitude radiolarians. The origin of these faunas in southern high latitudes is reasonable, if bipolar zoogeographic distribution of radiolarian faunas, such as those of the Neogene and today (e.g., Nigrini, 1967), also existed in the Cretaceous.

However, the non-Tethyan species tentatively included with the normal Cyrtocapsa, Eusyringium, Pseudoeucyrtis, Praeconocaryomma, and parvicingulids gen. et sp. indet. (Baumgartner, this volume) are unknown (also from the Boreal Realm) and should be assigned to new genera. Large relative abundances and rapid evolution of these species are documented in the sand faunas. Both features have no parallel in known Mesozoic radiolarian assemblages and are difficult to interpret. Few Early Cretaceous southern middle- to high-latitude radiolarians are known: an Aptian/Albian fauna recently reported by Ling and Lazarus (1990) from the Weddell Sea (Hole 693B), poorly preserved faunas from New Zealand (Spörli and Aita, 1988; Spörli et al., 1989), and well-preserved radiolarian faunas from the Windalia Radiolarite (Carnarvon Basin, West Australia, Ellis, 1978; Ellis et al., 1991). None of these faunas represents an equivalent of the Neocomian sand faunas at Site 765. However, the Aptian/Albian assemblages of the Argo Basin have many species in common 
EARLY CRETACEOUS BIOGEOGRAPHIC SYNTHESIS

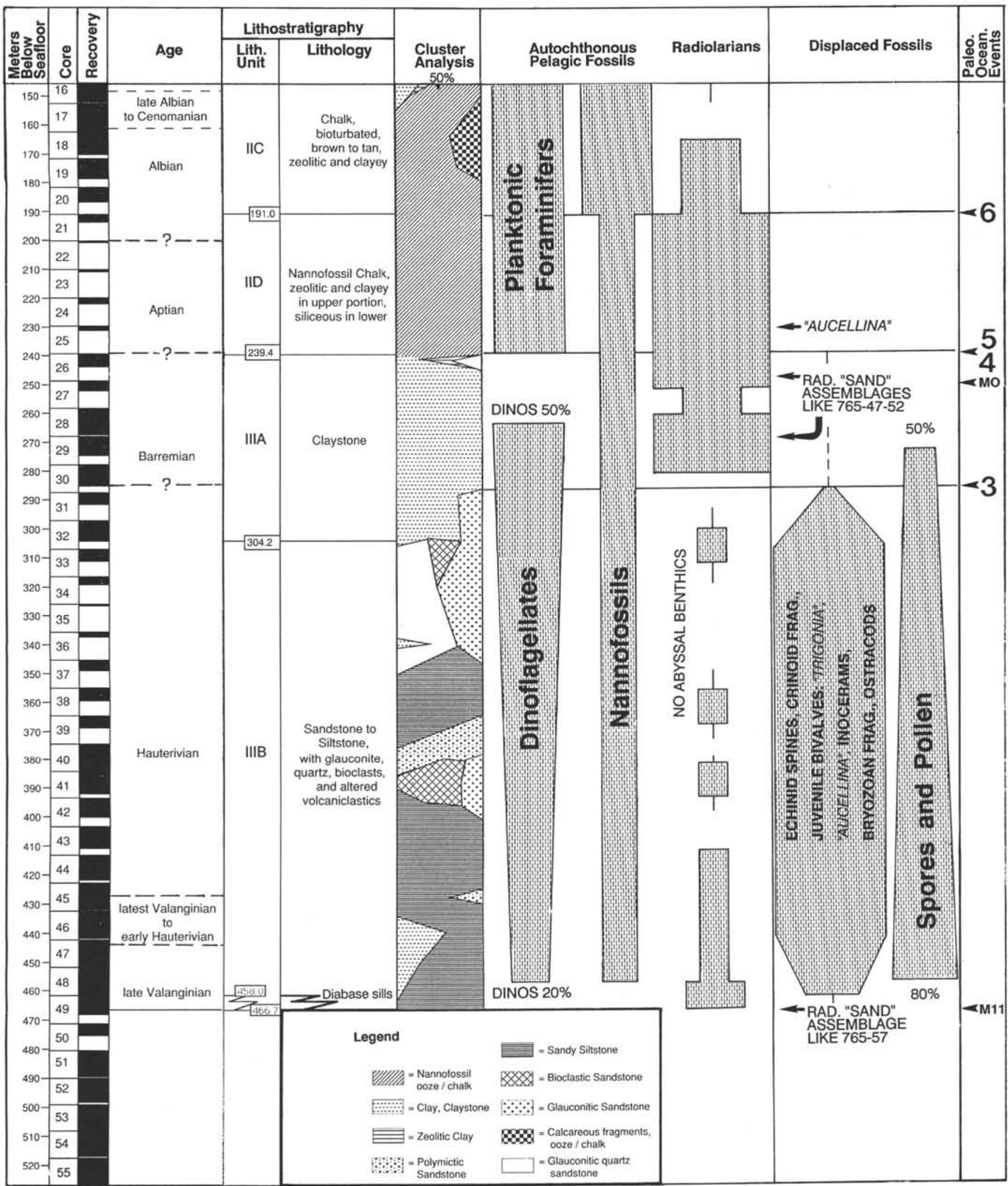

Figure 4. Lower Cretaceous cores, age, lithology, and generalized abundances of the principal fossil groups recovered at Site 766 and paleoceanographic interpretation. The column "Cluster Analysis" (taken from Ludden, Gradstein, et al., 1990, Chapter 5, back-pocket chart) shows lithologic variation vs. depth following smear slide data (see text). The principal paleoceanographic events are marked with the numbers 1 through 6 in Figures 3 through 6. "M11" and "M0" mark the inferred or observed level of these magnetic anomalies and refer to the plate-tectonic reconstructions given in Figure 5. For comments about Events 1 through 6, see text. Events 4 and 5 fall together because of low sedimentation rates, and the onset of both abundant planktonic foraminifers and radiolarians occurs earlier at this site than in the Argo Basin. 
with the coeval faunas cited from the Windalia Radiolarite and the Weddell Sea. Future work will be necessary to demonstrate the origin of the lineages observed in these sand faunas. These taxa are probably endemic to the southern high latitudes and may become important for defining the Austral radiolarian province.

The sedimentology of the radiolarite layers and the essential absence of these layers at the more distal Site 261 clearly indicate that the non-Tethyan radiolarians in the sand faunas were deposited near the Australian margin. These radiolarians are not indigenous to the Argo Basin; otherwise, they would also occur at the more distal Site 261. The origin and evolution of endemic radiolarians such as those observed in the sand faunas can only take place in large, well-defined oceanic water masses (Casey, 1971). Such an ocean may have existed around part of Antarctica, if one assumes an initial fit of Gondwana as proposed by Ricou et al. (1990), and a Late Jurassic to Early Cretaceous break-up of Gondwana, as shown in Figure 5. A proto-circumantarctic current system may also have existed. When the rift zone between India and western Australia subsided and reached oceanic depths, the proto-circumantarctic current system entered the seaway and transported circumantarctic radiolarian species into the Argo Basin (Fig. 5B). This hypothetical cold-water current entered the Argo Basin via the Exmouth Plateau and contoured the northwestern Australian continental slope. Upwelling, triggered by the current itself and/or by offshore winds, brought the cold-water taxa in contact with temperate surface waters, where they died and accumulated along the margin, in a manner similar to that described by Casey (1971) for the modern ocean. This radiolarian skeletal material became concentrated by the same contour current. Fluctuations in cold-water transport through the Indo-Australian Straits created fluctuations in radiolarian influx and concomitant bottom-current activity. These factors induced the foundations of the conspicuous radiolarite layers of Site 765.

In an alternative hypothesis, the non-Tethyan new genera and species may have had a bipolar zoogeography. The radiolarian lineages recorded in the sand faunas may have originated in the Boreal Realm and migrated across the Tethyan Realm as deepwater species. Their abundant occurrence along the northwestern Australian margin might then be explained by upwelling of deep, cool waters and local blooms in southern middle- to high-latitude high fertility conditions.

However, several observations contradict such a hypothesis:

1. The above-mentioned non-Tethyan, new genera have neither been observed in the Boreal Realm, nor in deep-water samples from the much better-known Tethyan Realm (Central Atlantic, Oceanic Tethys, Japan, Central and Eastern Pacific, Tethyan western North and Central America). No evidence exists for a bipolar zoogeography of these genera, in contrast to the new species of the genera Parvicingula and Ristola, discussed above, that may have Boreal relatives.

2. The absence of these new genera at Site 261 in the Central Argo Basin is most likely primary, because radiolarian sands are extremely rare in the Late Jurassic-Barremian interval at this site, and no species belonging to these new genera have been observed in the clay samples.

3. The only other radiolarian faunas that contain taxa comparable to the species seen in the younger sand faunas are the Aptian/Albian radiolarian fauna from the Weddell Sea (Hole 693B, Ling and Lazarus, 1990) and the assemblages of the Aptian/Albian Windalia Radiolarite on the western Australian continental shelf (Ellis, 1987).

In conclusion, these genera seem to be truly endemic to the Southern Hemisphere. They must have originated in a sufficiently large water mass. The preferred hypothesis in this chapter is an early connection between the circumantarctic basin and the Argo area, allowing for the influx of southern high-latitude waters that transported these endemic species.

\section{Benthic Foraminifers}

\section{Site 765 (Late Jurassic to Neocomian)}

The diversity of benthic foraminifers in Site 765 is highest in the Tithonian to Hauterivian section and declines steadily up the section. In general, red claystones contain diverse agglutinated assemblages; calcareous benthic foraminifers are rare and are restricted to calcareous turbidites. The Argo Abyssal Plain assemblages display a higher diversity of agglutinated taxa; the stratigraphic ranges of many of these taxa can be seen to differ considerably, compared with deep-water assemblages from Atlantic DSDP sites and from Poland.

The succession of benthic foraminiferal assemblages in Cores $123-765 \mathrm{C}-42 \mathrm{R}$ to $-62 \mathrm{R}$ can be subdivided into five assemblages, based on species diversity and stratigraphic occurrence of characteristic taxa (Kaminski et al., this volume). Diversities of up to 30 species were recorded for the Tithonian to Hauterivian interval. The deep-water agglutinated foraminifers (DWAF) in these claystones include several taxa that have not been reported previously from abyssal sediments of this age, such as Ammolagena clavata, Reophax duplex, Trochammina abrupta, and Hormosina excelsa. These species are typical of Upper Cretaceous DWAF assemblages, and their occurrence at Site 765 indicates that they have a longer geologic record than previously assumed.

From Cores $123-765 C-56 R$ to -55R, DWAF diversity declines markedly, to about 10 species, and the nature of the assemblages changes from "flysch-type" to assemblages dominated by Rhizammina and ammodiscids (Ammodiscus, Glomospira, and Glomospirella). These assemblages correspond to the "Biofacies B" Assemblage of Kuhnt et al. (1989) and Kuhnt and Kaminski (1989). This type of agglutinated assemblage contains many longranging forms and is a recurring feature of Cretaceous and Paleogene DWAF assemblages. Its occurrence is often associated with biosiliceous, radiolarian-rich sediments. At Site 765, the turnover from "flysch-type" DWAF to "Biofacies-B" DWAF occurs within lithologic Unit 6, which comprises carbonate turbidites, claystones, and radiolarian sands. The faunal change does not correspond to any distinct lithologic change, as radiolarian-rich layers are present throughout the interval from Cores $123-765 \mathrm{C}-60 \mathrm{R}$ to $-34 \mathrm{C}$. Kaminski et al. (this volume) attribute this faunal change to increased biosiliceous productivity. Alternatively, this turnover may have resulted from lowered and/or depleted ocean-floor oxygen levels, which are indicated by increasing TOC values (Heggie et al., this volume) and a greater frequency of green sediments (Cores 123-765C-52R to $-42 R$ ) that dominate above Core 123-765C-42R. This explanation is supported by the consistent occurrence of "Biofacies B" assemblages elsewhere in sediments indicative of oxygen-depleted bottom waters, for example, DSDP Hole 641A (Cenomanian/Turonian boundary); and DSDP Hole 603B (lower Turonian, lower Campanian) (Kuhnt et al., 1989).

Benthic foraminiferal assemblages from the Uppermost Jurassic to Lowermost Cretaceous sediments recovered at Site 261 are directly comparable to assemblages from Site 765 . However, many of these benthic foraminifers have extended lower ranges (Tithonian) and truncated upper ranges (upper Berriasian or lower Valanginian). The faunal change from "flysch-type" DWAF to "Biofacies-B" DWAF also is recorded at Site 261, but appears to take place at a slightly earlier level, in the early Valanginian. The diachroneity of the onset of "Biofacies B" may be related to local sedimentary environments, such as the depth of the site in relation to the calcite compensation depth (CCD) and/or the influx of 
biosiliceous sediments. In addition, the apparent difference may be exaggerated by problematical biostratigraphic constraints in the lower interval of both Sites 765 and 261.

Benthic foraminifers from the Argo sites do not compare favorably with DSDP sites from the North Atlantic (e.g., Site 534, Gradstein, 1983). Most of the "flysch-type" agglutinated elements are missing at Site 534, and common species (about 20 taxa) are restricted to ubiquitous cosmopolitan species such as Rhizammina spp., Glomospira spp., Glomospirella irregularis, Ammodiscus cretaceus, and so forth. A number of species from the North Atlantic have ranges in the Tithonian to Berriasian, but extend into younger stratigraphic horizons at Site 765 (e.g., Hippocrepina depressa, Bulbobaculites inconstans, Psuedoreophax, and Verneuilinoides neocomiensis). This pattern of truncated upper ranges in the North Atlantic can be attributed to differences in the sedimentary environments of the two ocean basins. In Site 534, this increasing carbonate and biosiliceous sedimentation results in rare and sporadic distribution of DWAF. In both the Atlantic and Indian oceans, the post-Hauterivian DWAF record is poor.

Bathyal DWAF assemblages from the northern margin of the Tethys are preserved in the flysch sequences of the Carpathians from Poland and Rumania. Many of the cosmopolitan species from Site 765 were first described from the Lower Cretaceous flysch deposits of the Polish Carpathians. In nearly all cases, the stratigraphic ranges of species at Site 765 overlap with their reported ranges in the Carpathians. In the case of Trochammina abrupta and Ammobaculoides, however, they are present during the Tithonian to Valanginian at Site 765 , but did not appear in the Carpathian troughs until later. This pattern may result from differences in paleobathymetry (bathyal vs. abyssal), or may imply the presence of a selective faunal barrier between the northern and southern margin of the Tethys.

\section{Site 766 (Aptian to Albian)}

The Aptian-Albian benthic foraminifer assemblages from Site 766 belong to the Marssonella Association and are similar to those recorded elsewhere along the Australian continental margin (Haig, this volume). They differ from assemblages of the Ammobaculites Association that are found within more restricted parts of the Australian epeiric basins (Haig, 1979, and this volume).

In general, the Australian faunas are composed of cosmopoli$\tan \operatorname{taxa}$, but lack many families that characterize the Tethyan paleo-equatorial belt. This decline in diversity from the equatorial belt south is thought to reflect a latitudinal temperature gradient (Scheibnerova, 1970; Haig, 1979).

\section{Discussion}

The paleobiogeographic distinctions recognized in the benthic foraminiferal assemblages reflect differences and changes in substrate and bottom-water conditions. The presence of species having extended or truncated stratigraphic ranges can be explained in this way, as can the occurrence of "Biofacies B." In addition, the presence of "Biofacies B" is thought to reflect depleted oxygen conditions, rather than increased biosiliceous influx to the substrate.

\section{Planktonic Foraminifers}

\section{Site 766 (Aptian to Albian)}

Planktonic foraminifers occur in all samples and include members of the Globigerinelloididae, Planomalinidae, Schackoinidae, Hedbergellidae, and Rotaliporidae families. Species of Hedbergella are the most common planktonic forms in most of the samples. A number of the Hedbergella species were also recorded from the "Great Artesian Basin" by Playford et al. (1975). Ticinella has not been definitely identified from the Australian region (one questionable specimen was recorded from Wharton Basin, DSDP Site 257), and its absence or rarity is a feature of all high-latitude sites in the southern ocean. The species is absent from Argo Abyssal Plain Sites 765 and 766 (Haig, this volume; Ludden, Gradstein, et al., 1990), Wharton Basin Site 257 (Herb, 1974; see note above), Naturaliste Plateau Site 258, and Weddell Sea Site 693 (Leckie, 1990). On the Falkland Plateau (Site 511), Ticinella is represented by only one common species in the lowermost Albian, which was interpreted as reflecting warmwater influence (Krasheninnikov and Basov, 1983). Similar observations can be made about the occurrences of Rotalipora, which is restricted to the middle Cenomanian on the Falkland Plateau. In all cases, closely related Hedbergella are relatively diverse and common, and they must represent a group more tolerant to cooler water temperatures in the high latitudes. The southern limit of Ticinella(?) and Rotalipora) appears to represent a useful biogeographic marker.

A further indication of latitudinal temperature changes is shown by comparing late Albian planktonic assemblages from the Papuan Basin Site 766 with Site 258 (Naturaliste Plateau). These sites represent a north-south transect through $15^{\circ}$ of latitude. Assemblages from the Papuan Basin and those from Site 766 are almost identical, but contrast markedly with those from Site 258 $\left(10^{\circ}\right.$ of paleolatitude farther south), which display a marked decrease in species diversity (Haig, this volume).

\section{Palynomorphs}

Helby and McMinn (this volume) have applied the Australian dinoflagellate biozonation without problems, but they have given no indication of how these floras relate to Tethyan ones. Mohr (1990) stated that Leg 113 palynomorphs (from the Weddell Sea) are similar in composition to Early Cretaceous microfloras from Australia and South America, but lack important elements characteristic of South America.

Strong floral affinities exist among the Antarctic peninsula, the Weddell Sea, and Australia, whereas some elements typical to Argentinean floras are absent (Mohr, 1990). A cool temperate rain forest mainly composed of podocarps and araucarian conifers can be inferred for the Valanginian to Hauterivian interval, based on miospore evidence found at Site 692 (Mohr, 1990). Coeval Neocomian megafloras from the Antarctic peninsula and southern Australia indicate strong seasonality, with prolonged dark winters and temperatures below freezing.

\section{Macrofossils}

The microfossil biogeographic interpretations presented above also are entirely compatible with recent biogeographic models that were based on macrofossil data. The late Mesozoic BorealTethyan macrofossil differentiation in the Northern Hemisphere is one of the most striking in the fossil record (e.g., Arkell (1956); Imlay (1965); Casey and Rawson (1973)). The equivalent Southern Hemisphere differentiation is mush less well documented and possibly less well developed (Crame, 1986). However, evidence is growing for a distinct Austral province for marine biota, at least for the interval from the Late Jurassic to the Late Cretaceous (e.g., Stevens, 1980; Stevens, 1989; Crame, 1986). Stevens (1980) reviewed the paleobiogeography of the southwest Pacific and described a major biogeographic shift that occurred at the end of the Jurassic. In Middle to Late Jurassic time, the region was characterized by major influxes of Tethyan elements and an absence of Austral faunas. Into the Early Cretaceous, "Palaeoaustral" elements gained importance, and Tethyan taxa declined markedly. Australia, New Zealand, Antarctica, and eastern India, all supported faunas having cool-temperature characteristics distinct from those of the Tethyan Realm (Stevens, 1980, fig. 4). This biogeographic shift was probably the result of various factors: 
A

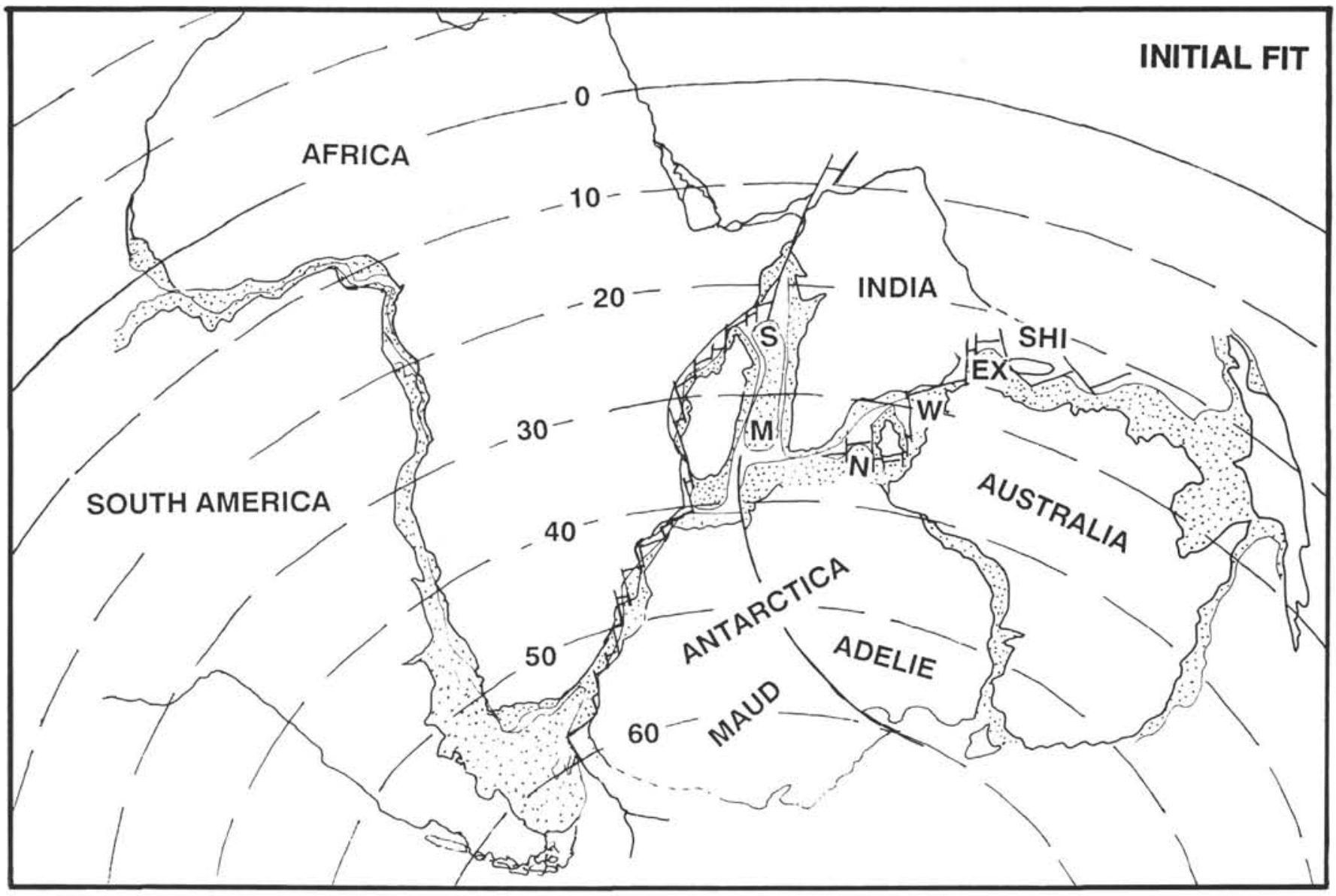

Figure 5. A. Initial fit of Gondwana as proposed by Ricou et al. (1990, slightly modified). These authors proposed splitting Antarctica into two parts (named Adelie and Maud) to obtain a closure of all gaps within the megacontinent. Areas underlain by (thinned) continental crust are stippled: Seychelles-Mascareignes (S-M), Naturaliste Plateau (N), Wallaby Plateau (W), and Exmouth Plateau (EX). An individual continental block opposite Northwest Australia, the Shillong Hills (SHI), is assumed. This fit and its Jurassic-Early Cretaceous break-up (B) is more consistent with the biogeographic data presented here than with fits of the du Toit type. B. Gondwanan paleogeography during the Early Cretaceous (late Valanginian, M11) after Ricou et al. (pers. comm., modified by hand drawing). A Jurassic break-up is assumed for the Somali Basin, the Madagascar Channel, the Mozambique and Weddell basins, and the Argo Basin. An Early Cretaceous rift zone separated India from Antarctica and Australia, which began to break up around M11. Stippled lines indicate inferred $2000-\mathrm{m}$ isobath. Jurassic and Early Cretaceous break-up led to oceanic seaways, isolating an Antarctic-Australian continental mass, which favored a clockwise proto-circumantarctic current system (solid arrows) that penetrated via the foundered plateaus through the Indo-Australian break-up into the Argo Basin. Branches of the South Equatorial Current in Tethys (stippled arrows) entered the Somali Basin and may have mixed south of the Madagascar Channel with the Circumantarctic Current system. The location of DSDP and ODP sites discussed in the text is indicated. C. Gondwanan paleogeography during the mid-Cretaceous (early Aptian, M0) after Ricou et al. (pers.comm., modified by hand drawing). Rapid spreading widened the Indian Ocean between India and Australia-Antarctica, which permitted an unconstrained flow of circumantarctic waters toward the east. Periodically, varying upwelling must have occurred along the Antarctic and the Australian margins (lined pattern). At this time, the Falkland Plateau had not yet cleared the tip of Africa and strongly anoxic conditions dominated in the southern Atlantic and the Mozambique Basin. By late Aptian/early Albian, further opening of the South Atlantic opened the Falkland barrier and the proto-Agulhas Current (finely stippled arrows) transported faunas with Tethyan affinities as far as the Falkland area. Mixing of Tethyan and high-latitude faunas observed off northwestern Australia may have been caused by such a mechanism or by a convergence developed off western Australia. 
B

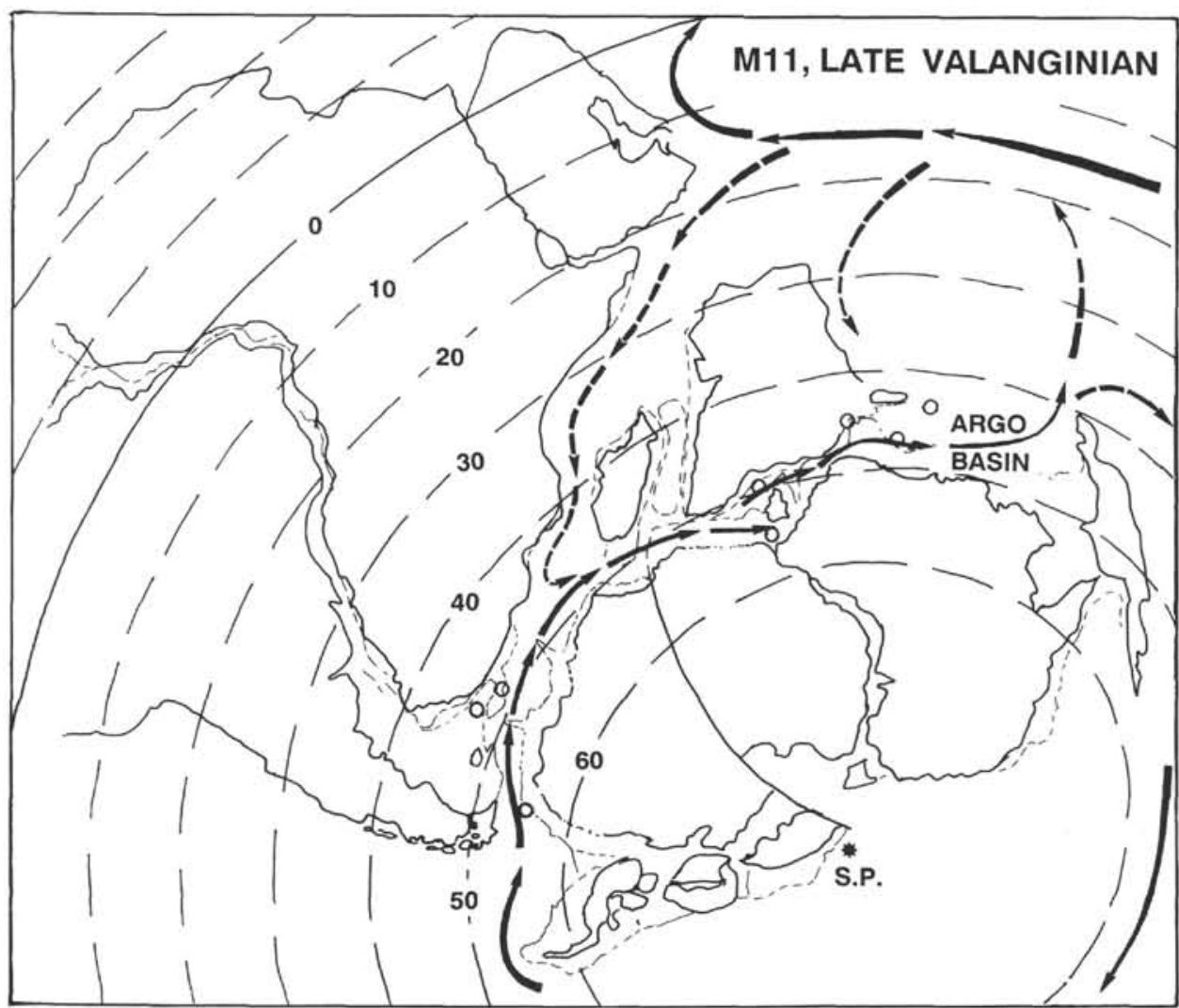

C

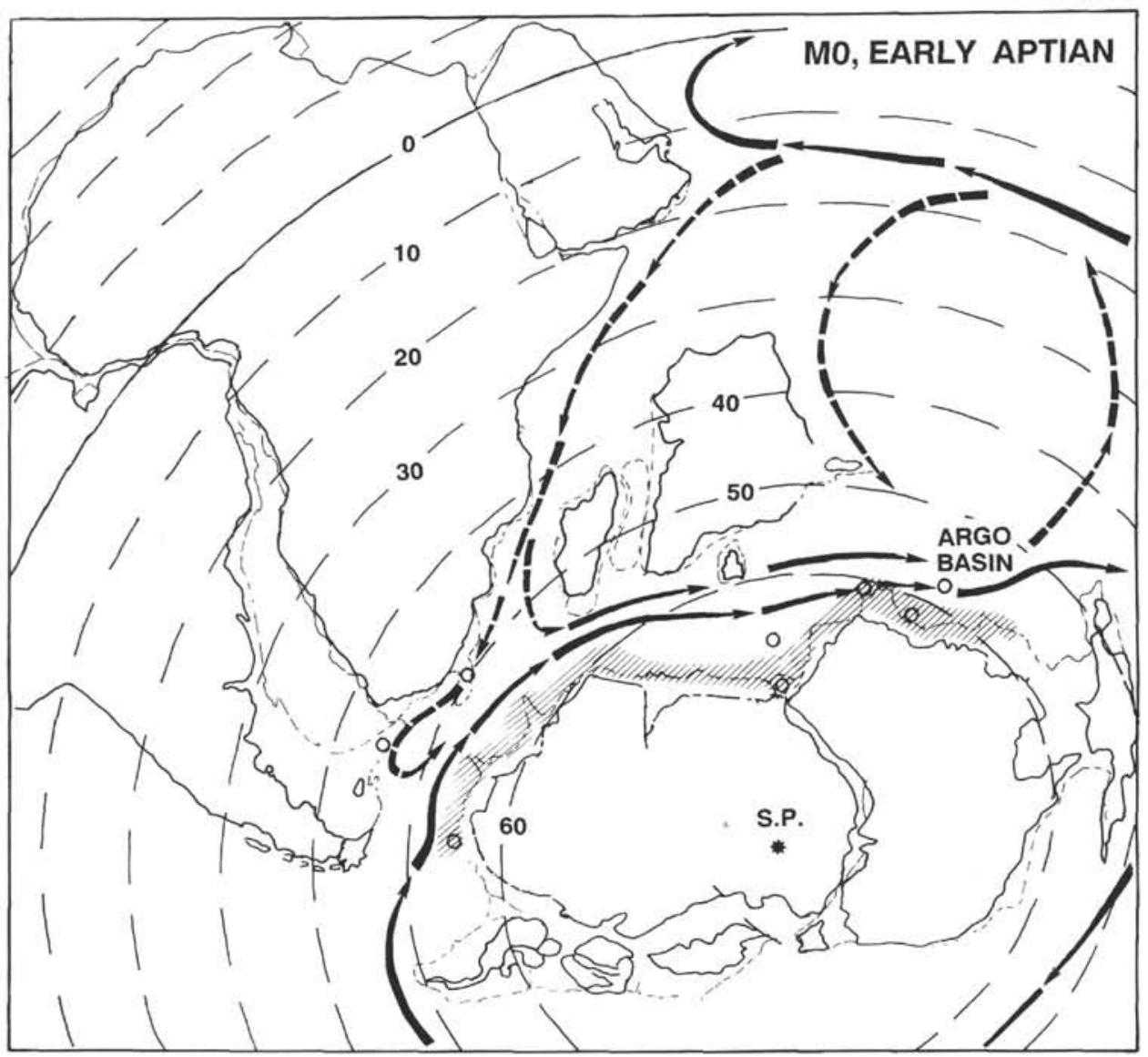

Figure 5 (continued). 


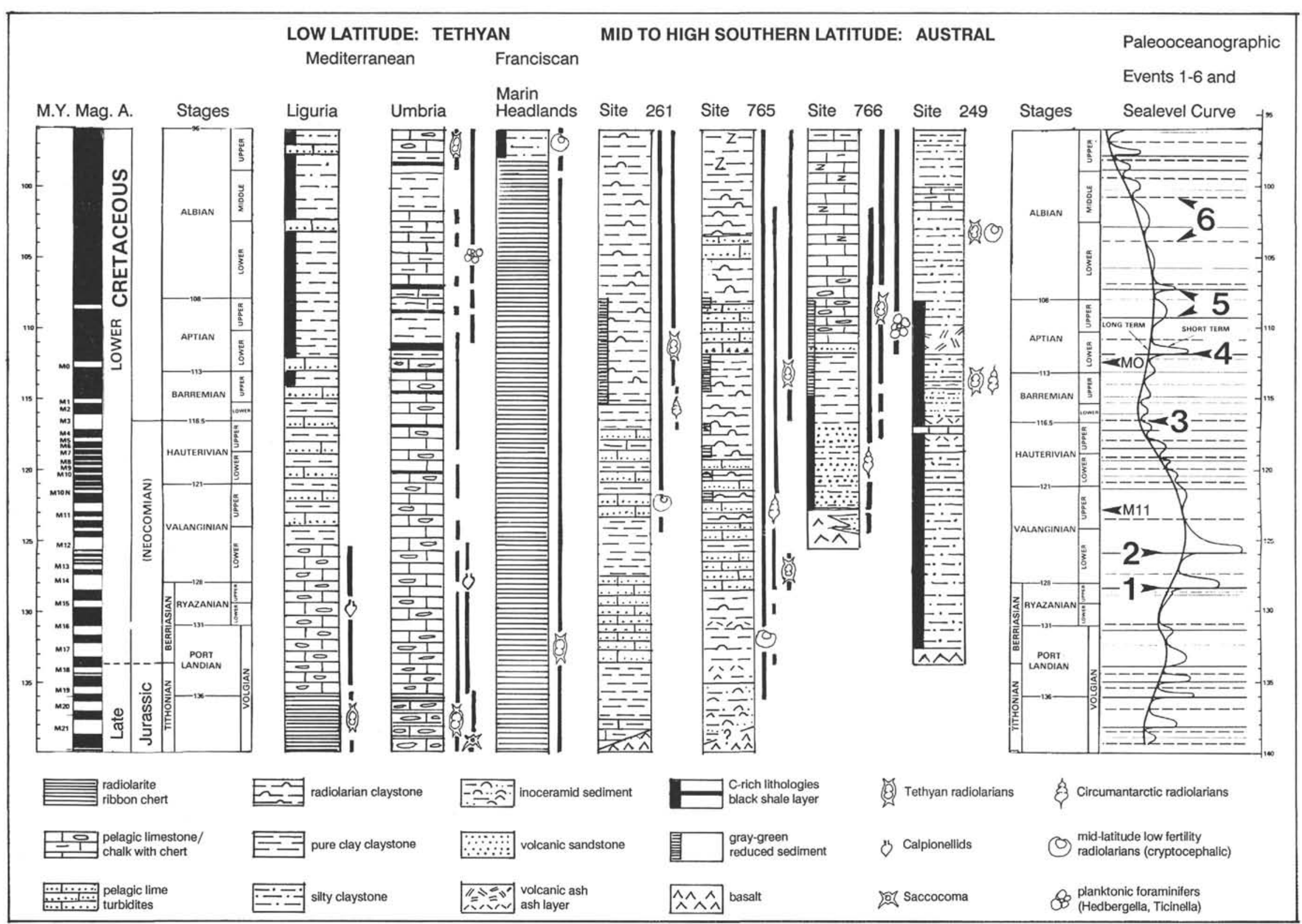

Figure 6. Chronostratigraphic comparison of Tethyan with Austral Early Cretaceous pelagic lithofacies and biofacies in different ocean basins, compiled after various sources given in the text. Note the dissimilarity of Tethyan, low-latitude sections and southern mid- to high-latitude sections, including the Argo-Exmouth area. Note that the time of reducing bottom conditions or organic-rich lithologies is basin-specific: in the Mediterranean Tethys, black shales were most abundant during Aptian-Albian time, whereas in the Marin Headlands, thought to be of open-ocean origin, black shales do not occur until the late Albian-Cenomanian, when the site approaches the continent. Southern high-latitude sites show organic-rich lithologies throughout the Neocomian, but are much less organic-rich in the Albian. The same is true for the Argo-Exmouth area, although TOC levels rarely exceed 1\%. Paleoceanographic Events 1 through 6 (see Figs. 3 and 4) are correlated with the sea-level curve by Haq et al. (1987). 
principally, the disruption of migration routes and changes in temperature that in turn were related to paleogeographic/oceanographic and climatic changes, as the break-up of Gondwanaland proceeded (Stevens, 1980).

\section{Inoceramids}

Evidence of bipolar bivalve distributions in the Kimmeridgian to Berriasian is growing. The genera Buchia, Retroceramus (inoceramid), Anopaea (inoceramid), and Arctosis (oxytomid) were restricted to the southern circum-Gondwana region (including northern Australia) and the northern high latitudes (Crame, 1986).

The abundance of inoceramid fragments in the Tithonian-Berriasian cores at Site 765 , and the occurrence of whole shells of "Aucellina" at Site 766 (Fig. 4) are features commonly observed at all cirumantarctic sites (Jones and Plafker, 1977; Doyle et al., 1990). This is another argument for southern Gondwanan, rather than Tethyan, affinities of the Exmouth-Argo area.

These bivalve distributions are interpreted as high-latitude temperate (or cool-temperate) faunas developed on either side (poleward $30^{\circ}$ ) of a broad tropical belt that was largely coincident with the Tethyan Ocean. This distribution is attributed to global climatic temperature gradients that, although perhaps less substantial than those of today, subjected the high-latitude regions to cool-temperate climatic regimes.

\section{Belemnites}

Late Jurassic and Early Cretaceous belemnite assemblages represent two separate faunal realms: Boreal and Tethyan. The Tethyan Realm (southern and central Europe, eastern Africa, Madagascar, Antarctica, South America, New Zealand, Indonesia, Australia, and India) was characterized by the Belemnopseidae, Duvaliidae, and Dicoelitidae. This faunal realm can be subdivided further into the Mediterranean Province (southern Germany, Alps, France, Spain, Morocco, Sicily, Crimea, and Bulgaria) without Belemnopsis, and the Indo-Pacific Province (eastern Africa, Antarctica, New Zealand, Indonesia, Australia, and India) dominated by endemic Belemnopsis. These provinces may be subdivided again into the Ethiopian and Indo-Pacific subprovinces of the Late Jurassic and the Ethiopian-Antarctic and Indonesian subprovinces of the Early Cretaceous (BerriasianHauterivian). The limited number of belemnite specimens recovered during Leg 122 (Mutterlose, this volume) exhibit close affinities to material described from Indonesia.

One specimen of Duvalia cf. D. sakalava was recovered from the Gascoyne Abyssal Plain (Sample 123-766A-42R-2, 41-43 $\mathrm{cm})$. This species has been described only from Madagascar and may indicate direct relationships with that area (Site 766 is located "downstream" with respect to Madagascar, if currents are assumed as illustrated in Fig. 6B).

\section{Remarks Regarding Tethyan Fossil Groups Not Found on the Northwestern Australian Margin}

\section{Saccocoma}

Skeletal fragments of Jurassic-Cretaceous free-swimming crinoids termed Saccocoma occur in rock-forming abundance in the Alpine-Mediterranean Tethyan Realm. The Saccocoma microfacies, easily recognized in thin section, displaying mass accumulations of Saccocoma ossicles, is found immediately below the calpionellid facies (Farinacci and Sirna, 1959) and may be limited to the Kimmeridgian-middle Tithonian time span (Borza, 1969; Remane, 1985). Saccocoma accumulations often display grading and lamination that suggest redeposition from pelagic swells into the basins.

No specimens of Saccocoma have been found in Uppermost Jurassic sediments of the Indian Ocean or the southern Atlantic. At least at Site 261, where calcareous Kimmeridgian-Tithonian lithologies definitely occur (Dumoulin and Bown, this volume). Saccocoma should have been detected, if this site experienced Tethyan influence at that time.

\section{Calpionellids}

Calpionellids, a small group of late Tithonian to late early Valanginian planktonic protozoans of unknown affinities (Remane, 1985), are widely distributed in the Tethyan Realm. Occurrences extend from eastern Mexico in the west to the Kiogar Nappes of Tibet (Heim and Gansser, 1939) in the east; calpionellids also may occur in central New Guinea (Rickwood, 1955). No calpionellids have been reported from any Pacific or Indian Ocean sites or adjacent land sections. According to Remane (1971), "Calpionella" schneebergeri from western Australia is certainly not a calpionellid. At both Sites 261 and 765, the Berriasian-Valanginian section contains abundant pelagic carbonate turbidites that should have revealed some calpionellids, if the Argo area had been influenced by the Tethyan Realm at that time.

\section{LITHOLOGIC CHARACTERISTICS OF SOUTHERN HEMISPHERE PELAGIC SEDIMENTS COMPARED WITH TETHYAN FACIES}

Comparison of pelagic lithofacies from different ocean basins and paleolatitudes reveals interesting paleoceanographic characteristics (Fig. 6). However, such comparisons do have limits, especially for the Southern Hemisphere Lower Cretaceous. Most of the sites show distinct sedimentary influences from adjacent margins (e.g., O'Connell, 1990) that are controlled by regional tectonic and climatic conditions, rather than oceanwide hydrography. Carbonate dissolution at depth partly or totally erased the calcareous plankton fossil record in many regions, hampering comparisons. On the other hand, the bathymetry and fluctuation through time of the carbonate dissolution levels (ACD, CCD, etc.) record both changing oceanographic conditions and rates of planktonic carbonate production, which may be interpreted in terms of paleobiogeography and paleoclimate.

The worldwide distribution of Lower Cretaceous pelagic sediments in the Tethyan (low-latitude) Realm is evidence of the importance of biogeography on the distribution of calcareous ("above CCD") and noncalcareous ("below CCD") facies. Central Atlantic and Alpine-Mediterranean Tethys indicate an onset of dominant carbonate sedimentation during the KimmeridgianTithonian (Fig. 6; Laubscher and Bernoulli, 1977; Baumgartner et al., 1980; Baumgartner, 1984, 1987, 1990; De Wever et al., 1986). A drastic increase in the productivity of calcareous nannoplankton, especially nannoconids, led to a sharp decline of the $\mathrm{CCD}$ in most western Tethyan basins and to the onset of pelagic limestones (Maiolica and Biancone formations, Weissert, 1979; Blake Bahama Formation in the central Atlantic, Jansa et al., 1979). DeWever et al. (1986) and other authors concluded that this change in sedimentation was a response to the formation of a global equatorial current system. However, nannofossil limestones are by no means a globally occurring phenomenon in the Early Cretaceous for regions outside the Tethyan Realm. In fact, radiolarites and radiolarian-bearing claystones seem to be the normal pelagic sediment from Oman (Hawasina Nappes, Bernoulli and Weissert, 1987) to the entire Pacific area (Fig. 6; Murchey, 1984), including Japan, western North and Central America (Baumgartner, 1987), and many DSDP and ODP sites, where Lower Cretaceous sediments overlying true ocean crust have been recovered. The Uppermost Jurassic-Lower Cretaceous 
carbonate sequences drilled in the Pacific, as at Site 167, apparently overlie thick ocean-island tholeiites (Tamaki and Larson, 1988). Thus, these carbonates slowly accumulated at shallow depths, above a shallow CCD.

Relatively thick and pure Lower Cretaceous nannofossil limestones apparently are restricted to the biogeographic domain, where nannofloras were developing profusely. Elsewhere, nannofossils were relatively scarce and other calcareous plankton were virtually nonexistent, whereas radiolarians thrived. As a consequence, the CCD was shallow, and pelagic carbonates formed only at comparatively shallow depths ( $<3 \mathrm{~km}[?])$.

Comparatively little is known about the Early Cretaceous pelagic sedimentation in the southern middle and high latitudes. The few Pacific sites that may have had Cretaceous paleolatitudes higher than $30^{\circ} \mathrm{S}$ (e.g., Sites 595/596) experienced chert/claystone sedimentation throughout the Early Cretaceous. Apparently, similar sediments accumulated in the oceanic sequences, now accreted in the Le May Group, which Holdsworth and Nell (in press) concluded occupied a position between $39^{\circ}$ and $70^{\circ} \mathrm{S}$ in the open Pacific. Our sites in the Argo Basin (261 and 765, Fig. 6) exhibit dominance of clay sedimentation throughout the Early Cretaceous. Radiolarian-rich sediments are scattered in currentsorted sand layers that are restricted to sites near the margin. Out in the basin, radiolarians are ubiquitous in the Neocomian claystones, but do not become common until the Aptian-Albian. Two phases of important carbonate influx occurred: (1) during the late Berriasian to early Hauterivian and (2) during the Aptian-Albian. Both phases are related to abundant resedimentation of carbonate ooze from the adjacent Exmouth and Scott plateaus (Dumoulin and Bown, this volume). These observations suggest that the floor of the Argo Basin was beneath the CCD during the entire Early Cretaceous, whereas the plateaus bordering the northwestern Australian continent were above the CCD. Pelagic carbonate originally deposited at low rates on these plateaus was resedimented into the basin. The Neocomian sequences of Leg 122 on the Exmouth Plateau are condensed and exhibit important hiatuses (Haq, von Rad, O'Connell, et al., 1990).

From a number of sites (Fig. 2) in the southern Atlantic on the Falkland Plateau (Sites 327, 330, and 511), in the Weddell Sea (Sites 692 and 693), and on the Mozambique Ridge (Site 249), Lower Cretaceous sediments were recovered that were reviewed by O'Connell (1990). A complete Neocomian section was penetrated only at Site 249 (Fig. 6), where the paleodepth was relatively shallow, and paleolatitude was lower than at the other sites. On the Falkland Plateau (Sites 330 and 511), a hiatus includes at least the Berriasian to Hauterivian. Where present, Neocomian sediments are dominantly organic-rich mudstones and claystones, with minor amounts of carbonate. O'Connell (1990) concluded that sedimentation took place under dysaerobic conditions, probably near upwelling zones. Aptian-Albian sediments are comparatively richer in pelagic carbonate and/or silica. The depositional regime changed during the late Aptian and early Albian to more oxygenated conditions that may have resulted from an increase in bottom-current activity in relation with the opening of the South Atlantic (O'Connell, 1990). This increased oxygenation coincides with the early Albian warm-water influence reported for the nannofossils and planktonic foraminifers in sites on the Falkland Plateau (see preceding observations). Increased oxygenation may have been the result of an intensification of the proto-Agulhas Current (see below).

In conclusion, we state that Lower Cretaceous sediments in the Argo Basin have more southern middle to high latitude than Tethyan attributes, although none of the mid-Cretaceous sections cored in the Argo Basin reach TOC-values as high as those from the southern ocean sites $(5 \%-15 \%)$. Except for some periods during the early Aptian, bottom waters were variably oxidized and supported a benthic foraminiferal fauna. Bottom-current activity was important during the Early Cretaceous because the Argo Basin was a pathway between mid and high latitudes.

\section{PALEOCEANOGRAPHIC EVENTS AT SITES 765 AND 766}

Changes in microfossil abundance and preservation at Sites 765 and 766 parallel distinctive lithologic changes (Figs. 3 and 4). The Leg 123 Shipboard Scientific Party (Ludden, Gradstein, et al., 1990, Figs. 51-54) quantified lithologic change by graphically representing the distribution of principal lithologies using multivariate analysis of all smear-slide lithologic data. In a first step, smear-slide compositional data were clustered by the average linkage method. A number of lithologic groups resulted and are represented in Figures 3 and 4 (column "cluster analysis") as different patterns. The relative frequency of these groups, averaged over one to three cores, is graphically represented as a percentage. Lithologic groups are sorted by grain size; fining is to the left. Lithologic changes visualized in that way, match major changes in faunal/floral composition and abundance. These changes are interpreted as the paleoceanographic events, discussed as follows.

Event 1 is characterized by the sharp onset of high-latitude bipolar nannofossils and radiolarite layers that contain the characteristic radiolarian sand faunas. Nannofossils become abundant in pelagic calciturbidites. Resedimented calcareous lithologies make up to $50 \%$ of the section. Rhodochrosite micronodules occur as both disseminated in the claystone matrix and as laminated and size-sorted layers. Lithology and faunas above horizon 1 are interpreted in terms of sudden influx of southern high-latitude waters carrying cirumantarctic radiolarians and nannofossils into the Argo Basin. Bottom-current activity increased and reworked the pelagic carbonate on the adjacent plateaus, which was then resedimented by turbidites in the Argo Basin. Bottom-current activity also lead to winnowing and concentration of radiolarian and rhodochrosite sands. Event 1 has been tentatively correlated with the late Berriasian/early Valanginian lowstand LBZ-2.1 of Haq et al. (1987; see Fig. 6).

Between Events 1 and 2, rare Tethyan radiolarians indicate some warm-water influence. Between Events 2 and 3, Tethyan radiolarian taxa are almost completely absent, whereas circumantarctic taxa show great, but fluctuating, abundances and rapidly succeeding acmes of distinctive radiolarian lineages. Highlatitude nannofossils are abundant in resedimented carbonates. This interval has been interpreted as a time of strong influx of cold southern high-latitude waters related to the pronounced early Valanginian lowstand LBZ-2.2 of Haq et al. (1987; see Fig. 6). Cool water conditions in the Argo Basin at this time excluded the presence of Tethyan taxa. The position of magnetic anomaly M11 in the column of Site 765 (Fig. 3) has been inferred from correlation of radiolarian acmes to Site 766 (Fig. 4) and marks the beginning of seafloor spreading in the Indo-Australian break-up, well after the first occurrence of high-latitude faunas.

At Site 766 (Fig. 4), a thick sequence of glauconitic sand and siltstones was deposited between M11 and Event 3. These lithologies contain reworked echinoderms, inoceramids, bryozoans, and ostracods, but no warm or shallow-water organisms that would indicate the presence of a carbonate platform in the source area of this material (the Exmouth Plateau). Microfossils have been highly diluted by detrital material. However, dinoflagellates gain in importance up the section, whereas spores and pollen diminish. Radiolarians are scattered, and nannofossils yield moderate abundances.

Above Event 3, Tethyan radiolarian taxa reappear, although circumantarctic taxa still dominate the assemblages. At Site 765, nannofossils are absent because of pronounced dissolution. Deep- 
water benthic foraminifers are scattered and are represented by the impoverished Biofacies-B. Palynomorphs are well preserved as a result of reducing conditions in the sediment. Up the section, radiolarians become less abundant and are absent from many samples. The lowest assemblage of planktonic foraminifers was recovered at Site 765 , in the early Aptian. Rhodochrosite is a constant component that may reach more than $10 \%$ of the sediment volume. At Site 766 sedimentation becomes hemipelagic above Event 3, while radiolarians become common to abundant. Several radiolarian assemblages can be correlated from Site 765 to Site 766 and confirm the position of the magnetic anomaly "M0" at Site 766. The increasing importance of Tethyan radiolarian taxa above Event 3 may reflect more equitable conditions resulting from a better paleoceanographic connection with the Tethys Ocean and/or in relation with the long-term HauterivianBarremian highstand LBZ-3 of Haq et al. (1987; see Fig. 4).

Event 4 marks the sudden onset of resedimented pelagic carbonate at Site 765 that contains rich nannofossil and planktonic foraminifer assemblages. Radiolarians are scattered, and preservation is poor. At Site 766, at least part of the early Aptian is represented by a hiatus or a condensed section (Haig, this volume). As a consequence, Events 4 and 5 may fall almost together. Abundant pelagic resedimentation in the Argo Basin and condensation at the foot of the Exmouth Plateau are possibly related to the early Aptian lowstand LBZ-4.1 of Haq et al. (1987; see Fig. $6)$.

Events 5 and 6 delimit the late Aptian-early Albian biosiliceous phase, which is characterized by common Tethyan radiolarians, planktonic foraminifers, and nannofossils along with typical high-latitude forms. While claystones dominate at Site 765 , sediments become essentially biogenic at Site 766 and contain even some radiolarian chert. This interval is correlative with the Windalia Radiolarite of the epicontinental Carnarvon Basin (western Australia, Ellis, 1987; Ellis et al., 1991). Correlation of Events 5 and 6 with changes in sea level is uncertain; this is discussed in the next section.

\section{PALEOCEANOGRAPHIC, PALEOCLIMATIC, AND PLATE-TECTONIC SCENARIOS FOR THE EARLY CRETACEOUS}

\section{Introduction: The Plate-Tectonic Frame}

A number of histories of Gondwanan fit and break-up have been proposed in recent years (reviewed by Ricou et al., 1990). It is beyond the scope of this chapter to review these fits and their plausibilities. Biogeographic data compiled in this chapter are suggestive of paleoceanographic conditions that can be compared to the various break-up histories proposed in the literature. Our observations indicate the following paleoceanographic events:

1. In the Late or Latest Jurassic, opening of the Argo Basin, which was paleoceanographically isolated from Tethys by its higher paleolatitudinal position and/or by enclosing landmasses.

2. During the Late Jurassic, opening of an ocean basin around east Antarctica (Weddell and Mozambique basins), which created space for the evolution of southern high-latitude endemism and bipolar distributions of radiolarians and nannofossils.

3. During the Berriasian, opening of a seaway connecting the circumantarctic area with the Argo Basin, which resulted in the influx of southern high-latitude waters and the immigration of radiolarian and nannofossil assemblages typical of the circumantarctic area.

Reconstructions of Gondwana of the du Toit-type (1937), characterized by a fit of the southeast Indian margin to Antarctica, have a west-Australian margin facing the Tethys Ocean. To ex- plain a break-up south of the Exmouth Plateau as young as M11 (late Valanginian), Veevers et al. (1975) and Powell et al. (1988) extrapolated "Greater India" to include a wedge the size of the entire Tibetan Plateau. This still does not provide a landmass facing the northwestern Australian margin prior to the opening of the Argo Basin in the Late (or Latest) Jurassic. Himalayan blocks cannot be candidates for these hypothetical landmasses facing western Australia because their breakoff from Gondwana occurred long before the Late Jurassic. Görür and Sengör (in press) considered it impossible that a major continental fragment now forming the Asiatic Tethysides might have broken off western Australia during the Late Jurassic-Early Cretaceous, because these fragments had already collided with Asia by that time. The opening of Neotethys occurred during the late Triassic or earlier. Therefore, the Late Jurassic Argo Basin cannot be part of Neotethys, but it may have been a marginal sea that might have separated from Neotethys by a hypothetical landmass.

In most reconstructions of the du Toit type, India remained attached to Antarctica until the late Valanginian (M11-M10) (e.g., Veevers et al., 1980; Johnson and Veevers, 1984; Powell et al., 1988; or Lawver et al., 1991) and a connection between the Weddell-Mozambique and the Argo basins was impossible prior to the Hauterivian-Barremian.

The fit proposed by Ricou et al. (1990) is the only one that meets most of the requirements implied by our biogeographic analysis. The loose fit between southeastern India and western Australia (Fig. 5A) is consistent with continental crust beneath the Naturaliste, Wallaby, and Exmouth plateaus. That fit allows for crustal extension and foundering of these plateaus, which led to the deposition of condensed pelagic sequences during the Berriasian-Valanginian at Sites 761, 762, and 763 (Mutterlose, this volume) prior to seafloor spreading in the break-up, which started in late Valanginian time (M11). Through these deeply submerged plateaus, circumantarctic waters first entered the Argo Basin, which resulted in biogeographic connections.

Late Jurassic spreading between Africa, southwestern India, and Antarctica (Fig. 5B) resulted in the expansion of new basins, in which endemic radiolarian communities developed well before Berriasian time.

The break-up history proposed in Figures 5B and 5C was provided by Ricou and his colleagues (pers. comm., 1991). The maps were redrawn from printouts using Terra Mobilis software. Africa remains fixed during the Early Cretaceous. As a consequence, Australia experienced a rapid southward movement from seafloor spreading. In this reconstruction, the Argo Basin originated in the Latest Jurassic at paleolatitudes of about $30^{\circ}$ to $40^{\circ} \mathrm{S}$, a value which is consistent with data by Ogg et al. (this volume). However, at M11 (late Valanginian) the Argo Basin was between paleolatitudes of $40^{\circ}$ and $50^{\circ} \mathrm{S}$ and at M0 (early Aptian), at about $60^{\circ} \mathrm{S}$. This reconstruction may need modification, because Ogg et al. (this volume) report little paleolatitudinal displacement of the Leg 123 sites during the entire Early Cretaceous. However, we would like to point out that paleolatitudinal comparisons with sites in the Weddell Sea and the Falkland Plateau suggest Aptian paleolatitudes of about $50^{\circ} \mathrm{S}$ for the Exmouth-Argo area, which is consistent with the proposed reconstruction. The circumantarctic current system inferred in this interpretation should flow along northwestern Australia between paleolatitudes of $50^{\circ}$ and $60^{\circ} \mathrm{S}$ without a major deflection to the north (Fig. 5C). Interpretations in this chapter consider both the case of a constant paleolatitude of about $35^{\circ} \mathrm{S}$ and the possibility of Aptian paleolatitudes of about $50^{\circ} \mathrm{S}$.

\section{Tithonian-Late Berriasian Time (Before Event 1)}

During Tithonian and Berriasian time, spreading widened the Argo Basin, which was a narrow embayment or marginal sea, 
possibly bounded to the north by a hypothetical landmass (e.g., the Shillong Block, Ricou et al., 1990) and to the south and west by the present-day northwestern Australian margin (Fig. 5B). The low-diversity radiolarian assemblages of the claystones reflect restricted paleoceanographic conditions that permitted the existence of only a few tolerant radiolarian species. These radiolarian assemblages are known from Tethys and elsewhere, but have not been previously reported from high latitudes. Preliminary comparisons suggest that these faunas, dominated by cryptocephalic nassellarians, reflect mid-latitude, low-fertility conditions. Nannofloras of this interval are made up predominantly of cosmopoli$\tan \operatorname{taxa}$, with some rare Tethyan elements. The sparse, severely etched nannofloras are often dominated by Watznaueria spp. The absence of endemic Boreal taxa prior to the latest Berriasian precludes high-latitude influence before that time. Many characteristic Tethyan taxa are completely absent, indicating only a moderate Tethyan influence at that time.

Gondwana was breaking up during the same time, and a new seaway between Africa, Antarctica, and western India was being created. This new oceanic watermass (Weddell and Mozambique basins, Madagascar Channel) was colonized by an endemic radiolarian fauna derived from northern high- and low-latitude ancestors that migrated into the area.

\section{Late Berriasian-Early Valanginian Time (Between Events 1 and 2)}

Late Berriasian-early Valanginian time was characterized by unstable paleoceanographic conditions in the Argo Basin and triggered by the Indo-Australian break-up and a possible glaciation (see below). Although the oldest oceanic crust in the IndoAustralian Straits did not form until the late Valanginian (M11), the rift zone and adjacent margins were sufficiently submerged to permit an intermittent "spillover" of circumantarctic cold water into the Argo Basin; the resulting current contoured the Australian margin. Cold-water radiolarians were periodically transported into this region, upwelled along the margin, came into contact with temperate surface waters, and died. Their skeletons sank and became concentrated by winnowing bottom currents that were periodically re-enforced by the cold-water influx from the south. At the same time, the first massive occurrence of the nannofossil, $S$. salebrosum is the most positive proof of high-latitude influence in the Argo area. Greatly increased pelagic turbidite influx from the plateaus bordering the Argo Basin during this time were interpreted by Dumoulin and Bown (this volume) as having resulted from increased erosional activity of bottom currents along these margins. Turbidity transport may have been activated by the two pronounced lowstands of sea level (Haq et al., 1987) during this time interval. Both lowstands apparently have been recognized worldwide and exceeded $100 \mathrm{~m}$ in amplitude (Haq et al., 1987). These lowstands may have been caused by glaciations that built up inland ice on the Antarctic-Australian continent. Oceanic seaways separated Antarctica and Australia from the remainder of Gondwana at this time. A proto-circumantarctic current system may have developed, resulting in a polar cold cell and eventual glaciation. A full spectrum of evidence and arguments of Early Cretaceous glaciations in the Northern Hemisphere has been reported by Kemper (1987). He advocated a series of cold periods, both during the early Valanginian and the late Aptian/early Albian (see below). Direct evidence for glaciation on the Australian continent has been reported by Frakes and Francis (1988): the Valanginian to Albian Bulldog Shale of the southwestern part of the Eromanga Basin (central Australia) contains glendonites and ice-rafted clasts of up to $3 \mathrm{~m}$ in diameter. This part of the basin was located at paleolatitudes higher than $65^{\circ} \mathrm{S}$. Changes in pelagic facies (dated as Valanginian and Aptian) in the Tethyan Realm were correlated by Weissert and Lini (1991) with major changes in the carbon isotope record. Stratigraphic intervals having decreased carbon isotope values were interpreted as times of decelerated carbon cycling resulting from a cooler, dryer climate. These phases are synchronous with the major Early Cretaceous lowstands in sea level.

\section{Late Valanginian-Late Hauterivian Time (Between Events 2 and 3)}

The late Valanginian-late Hauterivian interval was characterized by seafloor spreading in the Indo-Australian break-up zone (M11, late Valanginian) and rapid expansion of the seaway. As a consequence, cold-water influxes into the Argo Basin became more stable during this period, which probably affected the entire Argo Basin watermass. Typical Tethyan radiolarian species are virtually nonexistent, except for a few tolerant species. Welldefined, successive acmes of circumantarctic species of probable southern origin represent several evolutionary lineages unknown from the Tethys. These may characterize a southern high-latitude faunal realm that had been well established by this time. Nannoconus is entirely absent, whereas Seribiscutum salebrosum has a consistent and common occurrence throughout this interval. $\mathrm{Re}$ working of pelagic carbonate from the plateaus to the Argo Basin floor by turbidites intensified and reached a maximum toward the later part of this interval, after which it sharply declined just before the end of the Hauterivian.

\section{Barremian-Early Aptian Time (Between Events 3 and 4)}

An almost entirely unrestrained circumantarctic current system developed during the Barremian-early Aptian time interval (Fig. 5C). Circumantarctic radiolarians dominated the radiolarian faunas well into the Aptian. Meanwhile, the connection to the southern Tethys became well established, and more typically Tethyan species appeared in the Argo Basin and on the Exmouth Plateau. This area experienced more equitable climatic conditions during the late Barremian and earliest Aptian, despite possibly higher paleolatitudes, compared to the early Neocomian. Lower overall fertility during this time may have been the cause of this less- continuous radiolarian record. Nannofloras from this interval experienced a major floral turnover, which may have been caused by a change to open-oceanic conditions at the Barremian/Aptian boundary (Mutterlose, this volume). The Aptian assemblages are cosmopolitan, but Nannoconus (abundant throughout the Barremian-Albian in the Mediterranean area) is extremely rare in the sites off northwestern Australia.

\section{Late Aptian-Albian (Between Events $\mathbf{4}$ and 6)}

The wealth of biogeographic data available for this interval were summarized in the previous sections of this chapter. A number of interpretations are possible, some of which are outlined here. Further detailed analysis will be necessary to reach a more refined interpretation. For the first time, planktonic foraminifers became important in abundance and diversity. A distinct decrease in faunal diversity occurred between Sites 766 and 258, which can be interpreted as the result of a convergence zone, such as the antarctic convergence of the modern ocean. The absence of Ticinella off western and northwestern Australia was a high-latitude effect common to sites in the Weddell Sea and Falkland Plateau. The nannofloras, though of cosmopolitan nature, show distinct, southern high-latitude affinities, as evidenced by the first occurrence of bipolar Seribiscutum primitivum in the early Albian and by the continued, almost total absence of Nannoconus. The close similarity of planktonic assemblages among the Weddell Sea, Falkland Plateau sites, and the sites off northwestern Australia suggests similar paleolatitudes between $50^{\circ}$ and $60^{\circ} \mathrm{S}$ that are consistent with the plate reconstruction proposed in Figure 5C. 
Alternatively, these similarities imply a northward shift of biogeographic boundaries, if a paleolatitude at about $35^{\circ} \mathrm{S}$ is assumed for the Argo Basin (Ogg et al., this volume). Such a northward shift may have resulted from an eastern boundary current along Australia that transported cold, nutrient-rich waters into the middle latitudes.

A short episode of warm-water influx into the Falkland Plateau area is indicated by the occurrence of Nannoconus and Ticinella in upper Aptian/lowermost Albian sediments at Sites 511 and 327. Because the South Atlantic was still separated from the central Atlantic at that time, we speculate that a proto-Agulhas Current was active for the first time, with warmer subtropical waters flowing through the Madagascar Channel along the African margin and onto the Falkland Plateau (Fig. 5C). Anoxic conditions largely ceased by that time, and the Falkland Plateau cleared the tip of Africa, resulting in more open circulation in the South Atlantic (Shipboard Scientific Party, 1977). This warm-water episode demonstrates the sensitivity of the system to latitudinal exchange of water masses. The southern limit of Nannoconus and Ticinella occurrences was temporarily at a paleolatitude of about $50^{\circ} \mathrm{S}$ in the Atlantic, whereas this limit should have been at less than $35^{\circ} \mathrm{S}$ in our area off northwestern Australia, if paleolatitudes of Ogg et al. (this volume) were correct.

Late Aptian/early Albian radiolarian faunas have not been studied in detail, but are well preserved and diverse at Sites 261 and 766. These faunas have significant numbers of typically Tethyan taxa such as Acanthocircus, Sethocapsa euganea, and some pantanellids, among species unknown to the Tethys, but apparently common in the Weddell Sea. This evidence may indicate mixing of subtropical and antarctic water masses, which may have occurred in an Antarctic convergence zone. The upper Aptian/lowermost Albian section also contains the only radiolarian cherts recovered at Site 766 , which may be indicative of a high fertility period related to oceanic convergence in the basin and upwelling along the margin. This biosiliceous episode is recorded on the Australian margin as the Windalia Radiolarite present throughout the Carnarvon Basin (Hocking, 1988; Ellis, 1987; Ellis et al., 1991; Haig, this volume). Mixing of Tethyan and high-latitude faunal elements may be indicative of high latitudinal gradients and well-developed oceanic convergences typical of ice ages. The sea-level curve of Haq et al. (1987) shows a long-term lowstand (Fig. 6) and several short-term peak lowstands that may be related to cool climates, including glaciations. Both Kemper (1988) and Weissert and Lini (1991) provided independent evidence for a late Aptian/early Albian global cool climate, which possibly resulted in the build-up of polar ice caps.

\section{CONCLUSIONS}

The Mesozoic microfossil distributions described above have profound implications for microfossil paleobiogeography in the poorly known southern middle to high latitudes. Of particular interest are the calcareous nannofossil, radiolarian, and planktonic foraminifer assemblages, which are clearly distinct from those observed in the Tethyan Realm (low latitude). In this respect, our microfossil data complement drilling during a number of recent DSDP/ODP legs that penetrated Mesozoic sediments in the southern oceans (i.e., ODP Leg 113, Weddell Sea; DSDP Legs 36, 71, and 72, Falkland Plateau).

All the microfossil assemblages exhibit varying degrees of differentiation from those of the Tethyan and Boreal realms. These differences, which characterize the Austral Realm, are expressed in the following ways:

1. Endemic taxa, that is, taxa restricted to the Austral Realm.

2. Excluded taxa or taxa known from the Boreal and Tethyan, but not the Austral Realm.
3. Distinct assemblage compositions. Many taxa occur in lower or higher relative abundances in the Austral Realm, compared to the Tethyan and/or Boreal realms. Diversity is generally lower than in the Tethyan Realm.

4. Anomalous stratigraphic ranges. First and final appearances of taxa may be extended. A taxon that has an earlier first appearance in the Austral Realm is likely to have originated here and subsequently migrated north. A taxon that has a later last appearance than elsewhere is likely to have thrived in a particular niche of the Austral Realm, while it was rare elsewhere and therefore not represented in the fossil record. First and final appearances of taxa may be truncated as compared to the Tethyan Realm. This situation occurred when oceanographic conditions favorable for the migration of Tethyan taxa to the south lasted for periods shorter than the range of the taxa.

5. Bipolar distributions. Many taxa occurred abundantly both at high northern and southern latitudes as a result of favorable conditions (temperatures). The exchange across the Tethyan Realm may have taken place in deep (= cold waters [as for radiolarians]) or certain taxa may have migrated in a larval or resting stage that was more tolerant to environmental change. Indeed, radiolarian taxa that thrived in high latitudes occur as a rare fraction of Tethyan deep-water assemblages. However, no preserved fossil record of many taxa that migrated through the Tethyan Realm in small numbers may exist.

The microfossil and macrofossil evidence indicates biogeographic differences of broad significance, although regional factors were also undoubtedly influential. These differences were observed throughout the Late Jurassic to Early Cretaceous interval, but in the Barremian to Albian evidence of greater homogenization in both the nannofossil and radiolarian distributions is seen. At the coarsest level, the microfossils display significant differences from the Tethyan area, but show affinities with the northern and southern high-latitude regions. The similarity of these high-latitude areas flanking the Tethyan belt is most likely the result of latitudinal temperature differences, the faunas and floras of the Argo Basin, and other southern ocean sites, which reflects cooler surface-water temperatures. As in the Northern Hemisphere, it appears likely that biogeographic differences become significant poleward of $40^{\circ}$.

In conclusion, the available fossil data from DSDP and ODP sites off northwestern Australia indicate important southern highlatitude affinities and weak Tethyan influence throughout the Neocomian. This observation together with the young age of the Argo crust and plate-tectonic considerations suggest that the Argo Basin was not part of the Tethys Realm.

The biogeography of the Neocomian radiolarian and nannofossil assemblages provides evidence of a post-Tithonian seaway between the circumantarctic area and the Argo Basin that resulted in the influx of southern high-latitude water. This current may have had an important oceanographic effect on the Argo Basin by lowering surface-water temperatures (compounding the effects of latitudinal changes) and thus influencing the distribution of the other plankton groups.

This conclusion constrains models for the Gondwanan initial fit and break-up history. The fit proposed by Ricou et al. (1990) is favored. A loose fit between the western Australian margin and southeast India after Tithonian time may account for the deepwater connection with the Weddell-Mozambique basins, which became possible because of the drowned marginal plateaus. In fits of the du Toit type, India remained firmly attached to Antarctica until at least the Valanginian, making such a connection impossible.

After the Barremian, increasing Tethyan influence is evident in all fossil groups, although southern high-latitude taxa are still 
present. Biogeographic domains, such as the southern extension of Nannoconus and Ticinella, suggest paleolatitudes of about $50^{\circ} \mathrm{S}$ for the Exmouth-Argo area. This value is consistent with the Gondwanan break-up history proposed in this chapter (Fig. 5C) Alternatively, if the measured paleolatitudes of about $35^{\circ} \mathrm{S}$ of Ogg et al. (this volume) are true, these biogeographic limits were displaced northward at least $15^{\circ}$ along Australia, in comparison to the southern Atlantic. In this case, the proto-circumantarctic current was deflected northward into an eastern boundary current off Australia and transported circumantarctic cold water into the middle latitudes.

By late Barremian/early Aptian time, a convergence zone that brought cold, nutrient-rich waters in contact with temperate waters might have developed off western or northwestern Australia. Such a convergence might explain the mixing of Tethyan with southern faunal elements, especially radiolarians and nannofossils. Another indication of a convergence zone near the Australian margin is a significant gradient in Albian surface-water temperatures over $10^{\circ}$ latitude, evidenced by a sharp decrease in diversity of planktonic foraminifers between the Exmouth (Site 766) and the Naturaliste (Site 258) plateaus. High fertility conditions during the late Aptian/early Albian, reflected by radiolarian cherts at Site 766 and the Windalia Radiolarite on the Australian margin, are suggestive of coastal upwelling induced by margin parallel currents and/or offshore winds. These conditions are synchronous with a time of global cooling, low sea level, and possibly repeated build-up of polar ice caps.

\section{ACKNOWLEDGMENTS}

We thank the Ocean Drilling Program and its staff for their assistance and patience during the cruise and the final phases of this chapter. The Swiss National Science Foundation (Project Nos. 2.332-0.86 and 20-27633.89) is acknowledged for providing travel funds and financing laboratory work to P.O.B. Discussions with Julie Dumoulin clarified much of our sedimentologic arguments. We thank Jean Ricou and his colleagues, who generously provided us with preliminary printouts of their Gondwanan breakup history, used here. We acknowledge the rigorous reviews by B. Funnell and Bob Goll and the reviews and comments of Helmut Weissert and Glynn Ellis. Our sincere thanks go to Rosemary Sliney for drafting the figures.

\section{REFERENCES}

Aarseth, I., Bjerkli, D., Bjorklund, K. R., Boe, D., Helm, J. P., LorentzenStyr, T. J., Myhre, L. A., Ugland, E. S., and Thiede, J., 1975. Late Quaternary sediments from Korsfjorden, western Norway. Sarsia, 58:43-66.

Applegate, J. L., Bergen, J. A., Covington, J. M., and Wise, S. S., 1989. Lower Cretaceous calcareous nannofossils from continental margin drill sites off North Carolina (DSDP Leg 93) and Portugal (ODP Leg 103): a comparison. In Crux, J. A., and Van Heck, S. E. (Eds.), Nannofossils and their Applications: Chichester (Ellis Horwood), 212-222.

Arkell, W. J., 1956. Jurassic Geology of the World: Edinburgh (Oliver and Boyd).

Baumgartner, P. O., 1984. A Middle Jurassic-Early Cretaceous low-latitude radiolarian zonation based on unitary associations and age of Tethyan radiolarites. Eclogae Geol. Helv., 77:729-837.

1987. Age and genesis of Tethyan radiolarites. Eclogae Geol. Helv., 80:831-879.

1990. Genesis of Jurassic Tethyan radiolarites-the example of Monte Nerone (Umbria-Marche Apennines). Atti 2. Convegno, Fossili Evoluzione Ambiente. Editore Comitato Centenario Raffaele Piccinini, Pergola, 19-32.

Baumgartner, P. O., DeWever, P., and Kocher, R., 1980. Correlation of Tethyan Late Jurassic-Early Cretaceous radiolarian events. Cah. Micropaleontol., 1980/2:23-72.
Bernoulli, D., and Weissert, H., 1987. The upper Hawasina nappes in the central Oman Mountains: stratigraphy, palinspastics and sequence of nappe emplacement. Geodyn. Acta, 1:47-58.

Borza, K., 1969. Die Mikrofazies und Mikrofossilien des Oberjuras und der Unterkreide der Klippenzone der Westkarpaten. Slow. Akad. Wiss.

Bown, P. R., 1987. Taxonomy, evolution, and biostratigraphy of Late Triassic-Early Jurassic calcareous nannofossils. Spec. Pap. Palaeontol., 38:1-118.

Casey, R. E., 1971. Radiolarians as indicators of past and present watermasses. In Funnell, B. M., and Riedel, W. R. (Eds.), The Micropalaeontology of Oceans: Cambridge (Cambridge Univ. Press), 331-341.

Casey, R. E., and Rawson, P. F. (Eds.), 1973. The Boreal Lower Cretaceous. Geol. J. Spec. Iss., 5:1-448.

Casey, R. E., Gust, L., Leavesley, A., Williams, D., Reynolds, R., Duis, T., and Spaw, J. M., 1979a. Ecological niches of radiolarians, planktonic foraminiferans and pteropods inferred from studies on living forms in the Gulf of Mexico and adjacent waters. Trans. Gulf Coast Assoc. Geol. Soc., 29:216-223.

Casey, R. E., McMillen, K., Reynolds, R., Spaw, J. M., Schwarzer, R., Gevirtz, J., and Bauer, M., 1979b. Relict and expatriated radiolarian fauna in the Gulf of Mexico and its implications. Trans. Gulf Coast Assoc. Geol. Soc., 29:224-227.

Casey, R. E., Spaw, J. M., Kunze, F., Reynolds, R., Duis, T., McMillen, K., Pratt, D., and Anderson, V., 1979c. Radiolarian ecology and the development of the radiolarian component in Holocene sediments, Gulf of Mexico and adjacent seas with potential paleontological applications. Trans. Gulf Coast Assoc. Geol. Soc., 29:228-237.

Casey, R. E., Weinheimer, A. L., and Nelson, C. O., 1989. California El Ninos and related changes of the California current system from Recent and fossil radiolarian records. In Peterson, D. H. (Ed.), Aspects of Climate Variability in the Pacific and the Western Americas. Am. Geophys. Union, Geophys. Monogr., 55:85-92.

Caulet, J. P., 1974. Les Radiolaires des boues superficielles de la Mediterranée (The Radiolaria of the surficial sediments of the Mediterranean Sea). Bull. Mus. Natl. Hist. Nat. Sci. Terr., 249:217-288.

Cooper, M.K.E., 1989. Nannofossil provincialism in the Late JurassicEarly Cretaceous (Kimmeridgian to Valanginian) period. In Crux, J. A., and van Heck, S. E. (Eds.), Nannofossils and Their Applications: Chichester (Ellis Horwood), 223-246.

Crame, J. A., 1986. Late Mesozoic bipolar bivalve faunas. Geol. Mag., 123:611-618.

Crux, J. A., 1989. Biostratigraphy and paleogeographical applications of Lower Cretaceous nannofossils from northwestern Europe. In Crux, J. A., and van Heck, S. E. (Eds.) Nannofossils and Their Applications: Chichester (Ellis Horwood), 143-211.

De Wever, P., Ricou, L.-E., and Fourcade, E., 1986. La fin brutale de l'optimum radiolaritique au Jurassique terminal: l'effet de la circulation océanique. C. R. Acad. Sci. Ser. 2, 302:665-670.

Doyle, P., Crame, J. A., and Thomson, M.R.A., 1990. Late Jurassic-Early Cretaceous macrofossils from Leg 113, Hole 692B, Eastern Weddell Sea. In Barker, P. F., Kennett, J. P., et al., Proc. ODP, Sci. Results, 113: College Station, TX (Ocean Drilling Program), 443-448.

du Toit, A. L., 1937. Our Wandering Continents: an Hypothesis of Continental Drifting: Edinburgh (Oliver and Boyd).

Dyer, R., and Copestake, P., 1989. A review of late Jurassic to earliest Cretaceous radiolaria and their biostratigraphic potential to petroleum exploration in the North Sea. In Batten, D. J., and Keen, M. C. (Eds.), Northwest European Micropalaeontology and Palynology: Chichester (Ellis Horwood), 214-235.

Ellis, G., 1987. Lower Cretaceous radiolarian biostratigraphy and depositional environment of the Windalia radiolarite, Carnarvon Basin, western Australia [Requirement for Degree of B.S.]. Univ. Western Australia.

Ellis, G., Baumgartner P. O., and Haig, D. W., 1991. Lower Cretaceous radiolarian biostratigraphy and palaeooceanography from the West Australian margin. Abstract VII Interrad, Florence.

Erba, E., 1987. Mid-Cretaceous cyclic pelagic facies from the UmbrianMarchean Basin: what do the nannofossils suggest? INA Newsl., 9:52-53.

Farinacci, A., and Sirna, G., 1959. Livelli a Saccocoma nel Malm dell’Umbria e della Sicilia. Boll. Soc. Geol. Ital., 79:1-23. 
Frakes, L. A., and Francis, J. E., 1988. A guide to Phanerozoic cold polar climates from high-latitude ice rafting in the Cretaceous. Nature, 333:547-549.

Goll, R. M., and Bjorklund, K. R., 1972. Radiolaria in surface sediments of the North Atlantic Ocean. Micropaleontology, 17:434-454.

1974. Radiolaria in surface sediments of the South Atlantic. Micropaleontology, 20:38-75.

Görür, N., and Sengör, A.M.C., in press. Tethyan evolution of the Northwest Australian Margin: implications for the evolution of the Exmouth Plateau. In von Rad, U., Haq, B. U., et al., Proc, ODP, Sci. Results, 122: College Station, TX (Ocean Drilling Program).

Gradstein, F. M., 1983. Paleoecology and stratigraphy of Jurassic abyssal foraminifera in the Blake-Bahama Basin, Deep Sea Drilling Project Leg 76, Sites 533 and 534. In Sheridan, R. E., Gradstein, F. M., et al., Init. Repts. DSDP, 76: Washington (U.S. Govt. Printing Office), 537-560.

Haig, D. W., 1979. Global distribution patterns for mid-Cretaceous foraminiferids. J. Foraminiferal Res., 9:29-40.

Haq, B. U., Hardenbol, J., and Vail, P. R., 1987. Chronology of fluctuating sea levels since the Triassic. Science, 235:1156-1167.

Haq, B. U., and Lohmann, G. P., 1976. Early Cenozoic calcareous nannoplankton biogeography of the Atlantic Ocean. Mar. Micropaleontol., 1:119-194.

Haq, B. U., von Rad, U., O'Connell, S., et al., 1990. Proc. ODP, Init. Repts., 122: College Station, TX (Ocean Drilling Program).

Heim, A., and Gansser, A., 1939. Central Himalaya. Geological observations of the Swiss expedition 1939. Denkschr. Schweiz. Naturforsch. Ges., 73:1-245.

Herb, R., 1974. Cretaceous planktonic foraminifera from the eastern Indian Ocean. In Davies, T. A., Luyendyk, B. P., et al., Init. Repts. DSDP, 26: Washington (U.S. Govt. Printing Office), 745-770.

Hocking, R. M., 1988. Regional geology of the northern Carnavon Basin. In Purcell, P. G., and Purcell, R. R. (Eds.), The North West Shelf, Australia: Proc. Pet. Expl. Soc. Aust. Symp., 97-114.

Holdsworth, B. K., and Nell, P.A.R., in press. Mesozoic Radiolaria faunas from the Antarctic Peninsula and their geological significance. $J$. Geol. Soc. London.

Imlay, R. W., 1965. Jurassic marine faunal differentiation in North America. J. Paleontol., 39:1023-1038.

Jansa, L. F., Enos, P., Tucholke, B. E., Gradstein, F. M., and Sheridan, R. E., 1979. Mesozoic-Cenozoic sedimentary formations of the North American Basin; Western North Atlantic. In Talwani, M., Hay, W., and Ryan, W.B.F. (Eds.), Deep Drilling Results in the Atlantic Ocean: Continental Margins and Paleoenvironment. Am. Geophys. Union, Maurice Ewing Ser., 3:1-57.

Johnson, B. D., and Veevers, J. J., 1984. Australia's global setting: oceanic paleomagnetism. In Veevers, J. J., et al. (Eds.), Phanerozoic Earth History of Australia: Oxford (Oxford Univ. Press), 17-42.

Johnson, D. A., and Nigrini, C., 1980. Radiolarian biogeography in surface sediments of the western Indian Ocean. Mar. Micropaleontol., 5:111-152.

Jones, D. L., and Plafker, G., 1977. Mesozoic megafossils from DSDP Hole $327 \mathrm{~A}$ and Site 330 on the Eastern Falkland Plateau. In Barker, P. F., and Dalziel, I.W.D., et al., Init. Repts. DSDP, 36: Washington (U.S. Govt. Printing Office), 845-850.

Kemper, E., 1987. Das Klima der Kreide-Zeit. Geol. Jahrb., A96:5-185.

Kling, S. A., 1976. Relation of radiolarian distributions to subsurface hydrography in the north Pacific. Deep-Sea Res. Oceanogr. Abstr., 23:1043-1058.

Krasheninnikov, V. A., and Basov, I. A., 1983. Stratigraphy of Cretaceous sediments of the Falkland Plateau based on planktonic foraminifers, Deep Sea Drilling Project, Leg 71. In Ludwig, W. J., Krasheninnikov, V. A., et al., Init. Repts. DSDP, 71: Washington (U.S. Govt. Printing Office), 789-820.

Kuhnt, W., and Kaminski, M., 1989. Upper Cretaceous deep-water agglutinated benthic foraminiferal assemblages from the Western Mediterranean and adjacent areas. In Wiedmann, J. (Ed.), Cretaceous of the Western Tethys. Proc. 3rd Inter. Cretaceous Symp., Tübingen.

Kuhnt, W., Kaminski, M., and Moullade, M., 1989. Deep-water agglutinated benthic foraminiferal assemblages of the upper Cretaceous North Atlantic and its marginal seas. Geol. Rundsch., 78:1121-1140.

Labracherie, M., 1980. Les Radiolaires temoins de l'evolution hydrologique depuis le dernier maximum glaciaire au large du Cap Blanc
(Afrique du Nord-Ouest). Palaeogeogr., Palaeoclimatol., Palaeoecol., 32:163-184.

Labracherie, M., and Moyes, J., 1978. Oceanographie. Les Radiolaires indicateurs de la circulation des eaux oceaniques profondes. Exemple de 1'Atlantique nord-nord-oriental dans la region Faeroe Rockall. $C$. R. Seances Acad. Sci., Ser. D., 286:1425-1428.

Laubscher, H., and Bernoulli, D., 1977. Mediterranean and Tethys. In Nairn, A.E.M., Kanes, W. H., and Stehli, F. G. (Eds.), The Ocean Basins and Margins (Vol. 4A): New York (Plenum), 129-132.

Lawver, L. A., Royer, J., Sandwell, D. T., and Scotese, C. R., 1991. Evolution of the Antarctic continental margins. In Thompson, M. A., Crame, J. A., and Thompson, J. W. (Eds.), Geological Evolution of Antarctica: Cambridge (Cambridge Univ. Press), 533-539.

Leckie, R. M., 1990. Middle Cretaceous planktonic foraminifers of the Antarctic Margin: Hole 693A, ODP Leg 113. In Barker, P. F., Kennett, J. P., et al., Proc. ODP, Sci. Results, 113: College Station, TX (Ocean Drilling Program), 319-324.

Ling, H. Y., and Lazarus, D. B., 1990. Cretaceous radiolaria from the Weddell Sea: Leg 113 of the Ocean Drilling Program. In Barker, P. F., Kennett, J. P., et al., Proc. ODP, Sci. Results, 113: College Station, TX (Ocean Drilling Program), 353-363.

Ludden, J. N., Gradstein, F. M., et al., 1990. Proc. ODP, Init. Repts., 123: College Station, TX (Ocean Drilling Program).

McIntyre, A., and Bé, A.W.H., 1967. Modern Coccolithophoridae of the Atlantic Ocean. I: Placoliths and Cyrtoliths. Deep-Sea Res. Oceanogr. Abstr., 14:561-597.

Mohr, B.A.R., 1990. Early Cretaceous palynomorphs from ODP Sites 692 and 693, the Weddell Sea, Antarctica. In Barker, P. F., Kennett, J. P., et al., Proc. ODP, Sci. Results, 113: College Station, TX (Ocean Drilling Program), 449-465.

Murchey, B., 1984. Biostratigraphy and lithostratigraphy of cherts in the Franciscan Complex, Marin Headlands, California. In Blake, M. (Ed.), Franciscan Geology of Northern California: The Pacific Section. Spec. Publ.-Soc. Econ. Paleontol. Mineral., 43:51-70.

Murchey, B., and Jones, D. L., 1984. Age and significance of chert in the Franciscan complex, San Francisco bay region. In Blake, M. C. (Ed.), Franciscan Geology of Northern California: The Pacific Section, Spec. Publ.-Soc. Econ. Paleontol. Mineral., 43:23-30.

Mutterlose, J., 1989. Temperature-controlled migration of calcareous nannofossils in the north-west European Aptian. In Crux, J. A., and van Heck, S. E. (Eds.), Nannofossils and Their Applications: Chichester (Ellis Horwood), 122-142.

Mutterlose, J., in press. Das Verteilungs- und Migrationsmuster des kalkigen Nannoplanktons in der borealen Unterkreide (Valangin.Apt.) NW-Deutschlands. Palaeontographica B.

Mutterlose, J., and Wise, S. W., Jr., 1990. Lower Cretaceous nannofossil biostratigraphy of ODP Leg 113 Holes 692B and 693A, continental slope off East Antarctica, Weddell Sea. In Barker, P. F., Kennett, J. P., et al., Proc. ODP, Sci. Results, 113: College Station, TX (Ocean Drilling Program), 325-351.

Nigrini, C., 1967. Radiolaria in pelagic sediments from the Indian and Atlantic Oceans. Bull. Scripps Inst. Oceanogr., 11:1-125.

O'Connell, S. B., 1990. Sedimentary facies and depositional environment of the lower Cretaceous East Antarctic Margin: Sites 692 and 693. In Barker, P. F., Kennett, J. P., et al., Proc. ODP, Sci. Results, 113: College Station, TX (Ocean Drilling Program), 71-88.

Pessagno, E. A., 1977. Upper Jurassic Radiolaria and radiolarian biostratigraphy of the California Coast Ranges. Micropaleontology, 23:56113.

Pessagno, E. A., and Blome, C. D., 1986. Faunal affinities and tectonogenesis of Mesozoic rocks in the Blue Mountain Province of eastern Oregon and western Idaho. In Vallier, T. L., and Brooks, H. C. (Eds.), Geology of the Blue Mountains Region of Oregon, Idaho and Washington. Geol. Surv. Prof. Pap. U.S., 1435:65-78.

Pessagno, E. A., and Whalen, P., 1982. Lower and Middle Jurassic Radiolaria (multicyrtid Nassellariina) from California, east-central Oregon and the Queen Charlotte Islands, B. C. Micropaleontology, 28:111-169.

Petrushevskaya, M. G., 1971a. On the natural system of polycystine Radiolaria (Class Sarcodina). In Farinacci, A. (Ed.), Proc. 2nd Planktonic Conf. Roma: Rome (Ed. Tecnosci.), 981-992.

,1971b. Radiolyarii Nassellaria v planktone mirovogo okeana

(Radiolarians of the Ocean). Issled. Fauny Morei, 9:1-294. 
Playford, G., Haig, D. W., and Dettmann, M. E., 1975. A mid-Cretaceous microfossil assemblage from the Great Artesian Basin, northwestern Queensland. Neues Jahrb. Geol. Palaeontol. Abh., 149:333-362.

Pospichal, J. J., and Wise, S. W., Jr., 1990. Maestrichtian calcareous nannofossil biostratigraphy of Maud Rise ODP Leg 113 Sites 689 and 690, Weddell Sea. In Barker, P. F., Kennett, J. P., et al., Proc. ODP. Sci. Results, 113: College Station, TX (Ocean Drilling Program), 465-487.

Powell, C. McA., Roots, S. R., and Veevers, J. J., 1988. Pre-breakup continental extension in East Gondwanaland and the early opening of the eastern Indian Ocean. Tectonophysics, 155:261-283.

Proto Decima, F., 1974. Leg 27 calcareous nannoplankton. In Veevers, J. J., Heirtzler, J. R., et al., Init. Repts. DSDP, 27: Washington (U.S. Govt. Printing Office), 589-621.

Remane, J., 1971. Les calpionelles, protozoaires planctoniques des mers mésogéennes de l'époque secondaire. Ann. Guebhard, 47:1-25.

1985. Calpionellids. In Bolli, H., Saunders, J., and PerchNielsen, K. (Eds.), Plankton Stratigraphy. Cambridge (Cambridge Univ. Press), 555-572.

Renz, G. W., 1974. Radiolaria from Leg 27 of the Deep Sea Drilling Project. In Veevers, J. J., Heirtzler, J. R., et al., Init. Repts. DSDP, 27: Washington (U.S. Govt. Printing Office), 769-841.

1976. The distribution and ecology of Radiolaria in the Central Pacific plankton and surface sediments. Bull. Scripps Inst. Oceanogr., 22:1-267.

Rickwood, F. K., 1955. The geology of the western highlands of New Guinea. Aust. J. Earth Sci., 2:63-82.

Ricou, L.-E., Besse, J., Marcoux, J., and Patriat, P., 1990. Un fit Gondwanien revise sur donnees pluridisciplinaires. C. R. Acad.Sci.Ser. 2.

Roth, P. H., and Krumbach, K. R., 1986. Middle Cretaceous calcareous nannofossil biogeography and preservation in the Atlantic and Indian Oceans: implications for paleoceanography. Mar. Micropaleontol., 10:235-266.

Sancetta, C., 1978. Neogene Pacific microfossils and paleoceanography. Mar. Micropaleontol., 3:347-376.

Scheibnerova, V., 1970. Some notes on the palaeoecology and palaeogeography of the Great Artesian Basin during the Cretaceous. Search, $1: 125-126$

Shipboard Scientific Party, 1977. Evolution of the southwestern Atlantic Ocean Basin: results of Leg 36, Deep Sea Drilling Project. In Barker, P., Dalziel, I.W.D., et al., Init. Repts. DSDP, 36: Washington (U.S. Govt. Printing Office), 993-1014.

Spörli, K. B., and Aita, Y., 1988. Field Trip Guide to Waipapa Basement rocks, Kawakawa Bay, Auckland. Geol. Soc. N. Z. Misc. Publ., 39:128.

Spörli, K. B., Aita, Y., and Gibson, G. W., 1989. Juxtaposition of Tethyan and non-Tethyan Mesozoic radiolarian faunas in melanges, Waipapa terrane, North Island, New Zealand. Geology, 17:753-756.
Stevens, G. R., 1980. Southwest Pacific faunal palaeobiogeography in Mesozoic and Cenozoic times: a review. Palaeogeogr., Palaeoclimatol., Palaeoecol., 31:153-196.

1989. The nature and timing of biotic links between New Zealand and Antarctica in Mesozoic and Cenozoic times. In Crame, J. A. (Ed.), Origins and Evolution of the Antarctic Biota. Geol. Soc. Spec. Publ. London, 47:141-166.

Tamaki, K., and Larson, R. L., 1988. The Mesozoic tectonic history of the Magellan microplate in the western central Pacific. J. Geophys. Res., 93:2857-2874.

Tappan, H., 1980. The Paleobiology of Plant Protists: San Francisco (W. H. Freeman).

Veevers, J. J., Powell, C. McA., and Johnson, B. D., 1975. Greater India's place in Gondwanaland and in Asia. Earth Planet. Sci. Lett., 27:383387.

1980. Seafloor constraints on the reconstruction of Gondwanaland. Earth Planet. Sci. Lett., 51:435-444.

Vishnevskaya, V.S., 1988. O vozmoshnostyakh rascheleniya yursko-paleotsenovykh bulkanogenno-kremnistykh formatsii severo-zapadnogo obramleniya Pacifiki ( $v$ predelakh SSSR) (On the possibility of subdividing the USSR siliceous volcanic formations surrounding the northwest Pacific). In Pushcharovskii, Y. M. (Ed.), Ocherkii po geologii Kamchatki $i$ Koryakskogo nagorya (Reports on the geology of the Kamchatka and the Koryak Plateau): Moscow, USSR, Nauka, 8-15.

Weissert, H. J., 1979. Die Paläozeanographie de Südwestlichen Tethys in der Unterkreide. Mitt. Geol. Inst. Eidg. Tech. Hochsch. Univ. Zurich, N. Folge 226.

Weissert, H., and Lini, A., 1991. Ice age interludes during the time of Cretaceous greenhouse climate? In Müller, D. W., McKenzie, J. A., and Weissert, H. (Eds.), Controversies in Modern Geology: New York (Academic Press), 173-191.

Wise, S. W., Jr., 1983. Mesozoic and Cenozoic calcareous nannofossils recovered by Deep Sea Drilling Project Leg 71 in the Falkland Plateau region, Southwest Atlantic Ocean. In Ludwig, W. J., Krasheninnikov, V. A., et al., Init. Repts. DSDP, 71 (Pt. 2): Washington (U.S. Govt. Printing Office), 481-550.

, 1988. Mesozoic-Cenozoic history of calcareous nannofossils in the region of the Southern Ocean. Palaeogeogr., Palaeoclimatol., Palaeoecol., 67:157-179.

Date of initial receipt: 25 February 1991

Date of acceptance: 12 September 1991

Ms 123B-111 